\title{
Prevention of Chemotherapy-Induced Nausea and Vomiting in the Older Patient: Optimizing Outcomes
}

\author{
Jørn Herrstedt ${ }^{1,2}$ - Sanne Lindberg ${ }^{1} \cdot$ Peter Clausager Petersen ${ }^{1}$
}

Accepted: 17 November 2021 / Published online: 9 December 2021

(C) The Author(s), under exclusive licence to Springer Nature Switzerland AG 2021

\begin{abstract}
Chemotherapy-induced nausea and vomiting (CINV) are still two of the most feared side effects of cancer therapy. Although major progress in the prophylaxis of CINV has been made during the past 40 years, nausea in particular remains a significant problem. Older patients have a lower risk of CINV than younger patients, but are at a higher risk of severe consequences of dehydration and electrolyte disturbances following emesis. Age-related organ deficiencies, comorbidities, polypharmacy, risk of drug-drug interactions, and lack of compliance all need to be addressed in the older patient with cancer at risk of CINV. Guidelines provide evidence-based recommendations for the prophylaxis of CINV, but none of these guidelines offer specific recommendations for older patients with cancer. This means that the recommendations may lead to overtreatment in some older patients. This review describes the development of antiemetic prophylaxis of CINV focusing on older patients, summarizes recommendations from antiemetic guidelines, describes deficiencies in our knowledge of older patients, summarizes necessary precautions, and suggests some future perspectives for antiemetic research in older patients.
\end{abstract}

\section{Key Points}

Older patients have a lower risk for chemotherapyinduced nausea and vomiting (CINV) than younger ones.

Evidence-based CINV guidelines do not include specific recommendations for older patients with cancer.

This review summarizes the evidence for prophylaxis of CINV focusing on older patients with cancer.
Jørn Herrstedt

jherr@ regionsjaelland.dk

1 Department of Clinical Oncology and Palliative Care, Zealand University Hospital, Roskilde and Næstved, Sygehusvej 10, 4000 Roskilde, Denmark

2 Institute of Clinical Medicine, University of Copenhagen, Copenhagen, Denmark

\section{Introduction}

Approximately 19.3 million new cancer cases were diagnosed worldwide in 2020. This number is expected to increase to 28.4 million cases in 2040 [1]. Cancer is primarily a disease in older people and the number of individuals aged $\geq 70$ years diagnosed with cancer worldwide was approximately 7.2 million (37\% of all cases) in 2020 and is expected to increase to 13.6 million new cancer cases in 2040 , representing $48 \%$ of all new cases in 2040 [2]. This will have substantial economic and social impact. The fact that patients live longer after a cancer diagnosis will add to this burden [3].

Older patients present clinicians with challenges requiring knowledge and skills related to the complexities of managing multiple conditions concurrently. Issues like agerelated organ deficiencies, comorbidity, polypharmacy, and frailty have the potential to influence decisions on anti-cancer treatment and supportive care [4]. It is therefore of great importance that oncologists are skilled in treating cancer and treatment-related complications in the elderly.

Chemotherapy-induced nausea and vomiting (CINV) are still two of the most feared side effects of cancer therapy, but significant progress in prophylaxis and treatment has been made over the past 40 years [5]. Older patients seem to have a lower risk of CINV than younger patients [6], but on the 
other hand they are at a higher risk of severe consequences (e.g., dehydration, electrolyte disturbances) associated with CINV. In this review, we will discuss the specific circumstances of CINV focusing older patients with cancer.

\section{Risk Factors for Chemotherapy-Induced Nausea and Vomiting (CINV)}

\subsection{Chemotherapy-Related Risk Factors}

The emetic potential of antineoplastic drugs is defined by the Multinational Association of Supportive Care in Cancer as high (>90\%), moderate (30-90\%), low (10-30\%), and minimal $(<10 \%)$ risk of emesis within the first $24 \mathrm{~h}$ after initiating chemotherapy. Except for the combination of an anthracycline and cyclophosphamide (AC), classified as high risk, the risk classification concerns only single antineoplastic drugs [7]. Patients are today exposed to a range of antineoplastic drugs across the emetic risk categories such as classical cytostatics, targeted agents, and immune therapy. Fortunately, targeted agents and immune therapy are most often classified as minimal emetic risk or low emetic risk agents. An exception to this is the poly (ADP ribose) polymerase (PARP) inhibitors, which often cause nausea and sometimes vomiting in the first months after start of treatment. Doses of chemotherapy are often reduced in the elderly [8], but except for a few drugs, guidelines do not distinguish between chemotherapy doses when defining emetic risk potentials.

\subsection{Patient-Related Risk Factors}

Several patient-related factors affect the risk of CINV.

\subsubsection{Age}

A number of studies show that older patients have a lower risk of CINV than younger patients. This is reported both when age is set at a threshold (e.g., 60 years) [9] or as a continuous variable [10]. However, the impact of chemotherapyrelated side effects such as vomiting is greater in the elderly.

\subsubsection{Gender}

In randomized trials, women persistently have a higher risk of CINV than men $[11,12]$. The reason for this is unknown.

\subsubsection{Previous CINV}

Patients who have experienced nausea and/or vomiting during previous courses of chemotherapy are at an increased risk of CINV in subsequent cycles [6, 12]. In addition, a history of CINV with previous chemotherapy has been shown to increase the risk of CINV with current chemotherapy [13].

\subsubsection{Other Patient-Related Risk Factors}

Low alcohol intake, anxiety, anticipation of CINV, emesis in pregnancy, and motion sickness are all additional individual risk factors for CINV [12, 14, 15].

\subsection{Anti-emetic Prophylaxis}

Adherence to guidelines has been shown to increase the control of CINV in patients receiving chemotherapy with high or moderate emetic risk [16]. Optimal prophylaxis with antiemetics reduces the risk of acute emesis with cisplatin from almost $100 \%$ to $10-20 \%$.

\section{Considerations When Prescribing Chemotherapy and Anti-emetics for Older Cancer Patients}

\subsection{Physiology of the Elderly}

There is no universal definition of old age, but geriatric oncology is commonly defined as cancer in individuals aged 70 years or older [17]. Chronological age is, however, less important than biological age, because older people differ significantly in terms of physiological and psychological age-related ability. Individual assessment of suitability for cancer treatment and supportive care is therefore mandatory, rather than assessment based on chronological age alone [18].

Several age-related impairments should be considered in older patients with cancer. A change in drug absorption with ageing can be due to decreased esophageal, gastric, and colonic motility and/or to degeneration of villi in the small intestine [19].

Drug metabolism may be decreased by reductions in liver volume or cytochrome P450 enzymes, leading to increased bioavailability of some drugs. Reduced liver function may result in less protein binding of drugs, increasing the fraction of active drug. For example, the dose-adjusted exposure of the antiemetic olanzapine increases with age after oral administration, resulting in increased serum levels of olanzapine in older compared with younger adults [20]. This may explain the higher risk of sedation in older patients receiving olanzapine [5].

The glomerular filtration rate (GFR) normally declines from the fourth decade by around $1 \%$ per year $[21,22]$. This has implications for dosing and drug toxicity. While GFR can be easily estimated based on serum creatinine in younger 
patients, these estimations are often inaccurate in the elderly [23], meaning that the gold standard in older patients with cancer should be direct measurement of exogenous filtration markers such as ${ }^{51} \mathrm{Cr}$-EDTA.

Aging results in a decline in diastolic function and cardiac reserve due to left ventricular wall thickening as well as an increased prevalence of atrial fibrillation [24]. Examples of age-related heart disorders to consider are heart failure and arrhythmias, which may impact decisions regarding anticancer therapy and supportive care medications. In particular, $\mathrm{QT}_{\mathrm{C}}$ prolongation should be considered because this is a class adverse effect of the antiemetic group of 5 - $\mathrm{HT}_{3}$-receptor antagonists [25].

Bone marrow and bone density changes occur frequently in the elderly. The most apparent change in bone marrow function is decreased cellularity, estimated to be only $30 \%$ in those aged $\geq 65$ years as compared with younger people [26]. This likely contributes to the increased risk of chemotherapy-induced neutropenia [27] and thrombocytopenia observed in older patients with cancer.

Age-related cognitive impairment can be aggravated by cancer and antineoplastic therapy [28]. Difficulties with short-term memory can result in non-adherence to oral drug therapy [29]. Consequently, simple antineoplastic and antiemetic treatment regimens may be preferred in order to optimize compliance.

\subsection{Comorbidity}

Comorbidity in cancer patients is defined as the occurrence or the existence of any distinct additional medical condition to cancer [30]. Two in three older adults (aged 65 years or more) have at least one comorbidity and the number of comorbidities increases with age. Approximately $40 \%$ and $13 \%$ of older adults have three or more and five or more comorbidities, respectively [30]. It is known that older patients with cancer have a higher prevalence of comorbidity than an age-matched control group without cancer [31]. Also, the number and type of comorbidities differ with the type of cancer [31]. The difference in prevalence according to cancer diagnoses is likely explained by overlapping risk factors associated with both comorbidity and cancer; for example, smoking is a risk factor for both chronic obstructive pulmonary disease and lung cancer. Some of the most common comorbidities in patients with cancer are hypertension, cardiovascular disease, musculoskeletal or joint disease, diabetes mellitus, and pulmonary disease [32]. Different scales have been developed and validated to measure comorbidity burden, such as Charlson's Comorbidity Index (CCI) [33] and the Cumulative Rating Scale for Geriatrics [34]. When assessing cancer patients with comorbidity it is important to address how the comorbidity might affect prognosis, the impact of comorbidity on anticancer and supportive care therapy, and the potential effects of anticancer and supportive care therapy on comorbid diseases.

\subsection{Polypharmacy}

There is no consensus on the definition of polypharmacy, but the most frequently used define polypharmacy as the use of five or more medications [35]. Due to increased prevalence of multi-morbidity, physiological changes, and functional limitations, older patients with cancer have a high risk for polypharmacy, adverse drug reactions, and potentially inappropriate medications $[36,37]$. In a study of patients newly diagnosed with cancer and aged $70+$ years, $35 \%$ used five or more prescription medications daily [38]. The addition of non-prescription medication, antineoplastic agents, and supportive care agents (like antiemetics) will increase this number significantly. Polypharmacy results in high risk of potential drug-drug interactions that may have major implications for older patients with cancer, such as an increased risk of unplanned hospitalization [39]; consequently, antiemetics with a low risk of drug-drug interactions should be preferred in older patients with cancer.

\subsubsection{Antiemetics}

Until the 1960s, treatment of CINV was carried out on an empirical basis. CINV studies in the years 1960-1980 primarily included dopamine ${ }_{2}$-receptor antagonists or cannabinoids, but study methodology did not meet the requirements of today and only the first $24 \mathrm{~h}$ after initiation of chemotherapy were studied.

During the next 15 years (1980-1995), the primary focus was on studies with corticosteroids and serotonin $(5-\mathrm{HT})_{3}$ receptor antagonists. In particular, methodology of the $5-\mathrm{HT}_{3}$-receptor antagonist studies was improved and the study period often prolonged to include the first 5 days after chemotherapy.

The studies from 1995 to today have concentrated on the development of neurokinin (NK) ${ }_{1}$-receptor antagonists and lately on the multi-receptor targeting agent, olanzapine.

\subsection{Dopamine (D) $)_{2,3}$-Receptor Antagonists}

Dopamine was described as a brain neurotransmitter in 1957 [40]. Dopamine receptors are divided into five groups ( $D_{1}-D_{5}$ receptors), but only $D_{2}$ and $D_{3}$ receptors seem to be involved in the emesis pathway [41, 42]. Numerous $\mathrm{D}_{2}$-receptor antagonists have been studied, such as phenothiazines (metopimazine and prochlorperazine), butyrophenone (haloperidol), the substituted benzamide (metoclopramide), and the benzimidazole derivative (domperidone). The $\mathrm{D}_{2}$-receptor antagonists are not included in the fixed antiemetic regimens of the evidence-based guidelines of 
today [5], but are only recommended as rescue antiemetics. Recently, the $\mathrm{D}_{3}$-receptor antagonist, amisulpride, has been investigated in CINV [43].

\subsubsection{Metopimazine}

Metopimazine was investigated by Moertel and Reitemeier in two randomized, double-blind studies. In the first study, metopimazine $5 \mathrm{mg} \times 3$ orally was equal to metoclopramide $20 \mathrm{mg} \times 3$ orally, but none of the drugs were superior to placebo [44]. In the second study, metopimazine $(15 \mathrm{mg} \times 3$ orally) was equal to prochlorperazine but with less sedation, and both were superior to placebo [45]. Based on these studies, it was suggested to investigate metopimazine in higher doses. In two subsequent studies, it was then demonstrated that metopimazine in doses of $30 \mathrm{mg} \times 4$ orally increases the antiemetic effect of the 5- $\mathrm{HT}_{3}$-receptor antagonist, ondansetron, in CINV [46, 47]. In contrast to the majority of the other $\mathrm{D}_{2}$-receptor antagonists, metopimazine does not induce extrapyramidal adverse effects because of its low penetration of the blood-brain barrier [48]. Metopimazine delays gastric emptying, and constipation is therefore an adverse event in 10-20\% of patients. Unfortunately, metopimazine is not globally available and therefore of only limited research interest.

\subsubsection{Prochlorperazine}

Prochlorperazine is superior to placebo against CINV induced by chemotherapy of low and moderate emetic risk [44] and inferior [49] or equal to metoclopramide [50]. A number of studies have compared prochlorperazine to a cannabinoid, but primarily in patients who were refractory to prochlorperazine in previous courses of chemotherapy, meaning that no conclusions can be drawn [51]. A recent study has demonstrated activity of prochlorperazine in combination with dexamethasone against delayed CINV [52].

\subsubsection{Metoclopramide}

Metoclopramide is the $\mathrm{D}_{2}$-receptor antagonist that is best studied. It is a substituted benzamide derived from procainamide (methoxychloroprocainamide) and was first described by Justin-Besancon in 1964 [53]. Metoclopramide was effective against nausea and vomiting induced by a number of non-malignant conditions [54]. In low doses $(20 \mathrm{mg} \times 2-3$, orally), metoclopramide was no better than placebo [44] and inferior to dexamethasone and domperidone [55]. The interest in investigating metoclopramide further was therefore modest until Gralla and coworkers [56] demonstrated the significant effect of high-dose metoclopramide $(2 \mathrm{mg} /$ $\mathrm{kg}$ intravenously $[\mathrm{IV}] \times 5$ ) against cisplatin-induced nausea and vomiting. Subsequent studies optimized the high-dose metoclopramide regimen, by comparing the $2 \mathrm{mg} / \mathrm{kg}$ IV $\times 5$ regimen with a continuous infusion [57] or with two IV bolus infusions only [58, 59]. Acute dystonic reactions induced by high-dose metoclopramide were a significant problem, but the addition of diphenhydramine or lorazepam resulted in a significant reduction in the incidence of extrapyramidal adverse effects [58]. A modified high-dose metoclopramide regimen $(3 \mathrm{mg} / \mathrm{kg} \mathrm{IV} \times 2$ or $4 \mathrm{mg} / \mathrm{kg} \mathrm{IV} \times$ 1) combined with dexamethasone and lorazepam or diphenhydramine (to decrease the incidence of extrapyramidal adverse effects) became the standard antiemetic regimen in cisplatin-based chemotherapy [58] until the early 1990s. Metoclopramide has a prokinetic effect on the GI tract, and diarrhea is therefore a frequent adverse effect. It was soon verified that the antiemetic effect of high-dose metoclopramide was not caused by antagonism at $\mathrm{D}_{2}$-receptors, but was caused by antagonism at $5-\mathrm{HT}_{3}$-receptors [60-63]. This led to the development of a new class of antiemetic agents, the serotonin-receptor antagonists.

\subsubsection{Domperidone}

Domperidone was investigated in high doses in a number of studies in the 1980s in order to explore a possible dose-effect relationship like the one seen with metoclopramide. Unfortunately, high doses of domperidone induced cardiac adverse effects (cardiac arrest and sudden death) in a number of patients [64-67]. Consequently, the parenteral formulation was withdrawn from general use. In low IV doses or oral doses of $20 \mathrm{mg} \times 3$, domperidone was superior to placebo [68], inferior [69] or superior [55] to metoclopramide, and inferior [69] or equal to dexamethasone [55]. Like metoclopramide, domperidone has a prokinetic effect on the GI tract and diarrhea is a frequent adverse effect. Extrapyramidal adverse effects are rarely seen, because the penetration of the blood-brain barrier is limited [48].

\subsection{Corticosteroids}

The first randomized double-blind study was published in 1979 and concluded that dexamethasone was superior to placebo in patients receiving non-cisplatin chemotherapy [70]. Subsequent studies supported the finding that singleagent corticosteroids possess an antiemetic effect in patients receiving chemotherapy with low and moderate emetic risk $[55,71]$. When prescribed to patients receiving chemotherapy with moderate or high emetic risk, corticosteroids improve the effect of other antiemetics such as the $5-\mathrm{HT}_{3}$ receptor antagonists [72,73]. Dexamethasone is the best investigated agent, but there is no reason to believe that there are major differences between dexamethasone and prednisolone. Recently, a number of studies have compared a 1-day regimen of dexamethasone with a 3-day regimen 
('steroid-sparing regimens'). In patients receiving carboplatin-based or AC-based chemotherapy and a three-drug combination as antiemetic prophylaxis (a 5- $\mathrm{HT}_{3}$-receptor antagonist, a $\mathrm{NK}_{1}$-receptor antagonist, and dexamethasone), no major differences were observed between the 1-day and 3 -day regimens of dexamethasone. This is also acknowledged in the recently published guidelines (see Sects. 5.3 and 5.4).

\subsection{Serotonin $(5-\mathrm{HT})_{3}$-Receptor Antagonists}

Serotonin (5-HT) was discovered in 1948. 5-HT receptors are divided into seven groups $\left(5-\mathrm{HT}_{1}-5-\mathrm{HT}_{7}\right)$ with $5-\mathrm{HT}_{3}$ receptors as the most important in the emesis pathway. The 5 - $\mathrm{HT}_{3}$-receptor antagonists are the most effective antiemetics in the prophylaxis of acute nausea and vomiting $(0-24 \mathrm{~h}$ after initiation of chemotherapy), whereas the effect against delayed nausea and vomiting (24-120 h after initiation of chemotherapy) is modest. There are only minor differences between the $5-\mathrm{HT}_{3}$-receptor antagonists as concerns effect and tolerability. A large number of 5- $\mathrm{HT}_{3}$-receptor antagonists have been marketed, but only the most frequently used (ondansetron, granisetron, and palonosetron) will be addressed. The first two clinical studies were published in $1987[74,75]$. The most important studies are summarized in Tables 1, 2 and 3.

\subsubsection{Ondansetron}

Ondansetron was initially compared with single antiemetic agents and found to be superior to placebo in the prophylaxis of CINV induced by high-risk [76] and moderate emetic risk [77] chemotherapy and to high-dose metoclopramide in prophylaxis of CINV induced by chemotherapy with high emetic risk [78]. In patients receiving chemotherapy with moderate emetic risk, ondansetron was either superior [79, 80] or equal to [81] metoclopramide in the prophylaxis of acute nausea and vomiting, but without any significant difference in the delayed phase. A study compared ondansetron with dexamethasone in patients treated with moderate emetic risk chemotherapy and concluded that both antiemetics were equal in prevention of acute nausea and vomiting, whereas dexamethasone was superior in prophylaxis of delayed nausea [82]. As previously mentioned, dexamethasone improves the effect of ondansetron [72].

\subsubsection{Granisetron}

In contrast to the development of ondansetron, granisetron was initially compared with antiemetic combination regimens. In patients receiving moderate emetic risk chemotherapy, granisetron was superior to a combination of prochlorperazine and dexamethasone in the prophylaxis of acute emesis [83], and granisetron was as effective as a combination of high-dose metoclopramide, dexamethasone, and diphenhydramine in patients receiving cisplatin-based chemotherapy with high emetic risk [84]. As for the other 5 - $\mathrm{HT}_{3}$-receptor antagonists, the effect is improved by the addition of dexamethasone [73]. Two large randomized, double-blind studies compared oral granisetron with intravenous ondansetron $[85,86]$ and found no differences in efficacy and tolerability. In a subsequent randomized, doubleblind study, extended-release granisetron was noninferior to palonosetron [87].

\subsubsection{Palonosetron}

Palonosetron was marketed in 2003 (more than 10 years after ondansetron and granisetron), and the phase III pivotal trials consequently used a noninferiority design and compared palonosetron with two of the older 5- $\mathrm{HT}_{3}$-receptor antagonists. Two randomized, double-blind studies in patients receiving single-agent chemotherapy with moderate emetic risk or AC or low-dose cisplatin $\left(<50 \mathrm{mg} / \mathrm{m}^{2}\right)$ compared palonosetron with ondansetron [88] and dolasetron [89], respectively. Palonosetron was statistical significantly superior to ondansetron [88] and noninferior to dolasetron [89] in terms of patients with a complete response (CR) in the acute phase (no emesis and no need for other antiemetics 0-24 h after initiation of chemotherapy). In a third study, palonosetron was noninferior to ondansetron in prevention of acute nausea and vomiting in patients receiving cisplatin-based, high-emetic-risk chemotherapy [90]. In contrast to the two previously mentioned studies $[88,89], 67 \%$ of patients in both study arms received dexamethasone. In a large, randomized, double-blind, phase III post-marketing trial, palonosetron plus dexamethasone was compared with granisetron plus dexamethasone in patients receiving high-emetic-risk chemotherapy [91]. Palonosetron plus dexamethasone was noninferior to granisetron plus dexamethasone in the acute phase, but superior in the delayed phase.

\subsubsection{Adverse Effects and Potential Drug-Drug Interaction Risks}

The 5- $\mathrm{HT}_{3}$-receptor antagonists are generally well tolerated, with constipation, headache, slight reversible increase in liver transaminases, and $\mathrm{QT}_{\mathrm{C}}$ prolongation as drug class adverse effects. The 32-mg dose of ondansetron and the intravenous formulation of dolasetron were both withdrawn from the market due to FDA warnings $\left(\mathrm{QT}_{\mathrm{C}}\right.$ prolongations). Palonosetron seems to have a low risk and did not cause QTc prolongation when investigated in 221 healthy volunteers, but the mean age of the volunteers was 41 years, which is approximately 25 years younger than the average cancer patient [92]. A few reports of palonosetron QTc prolongation 


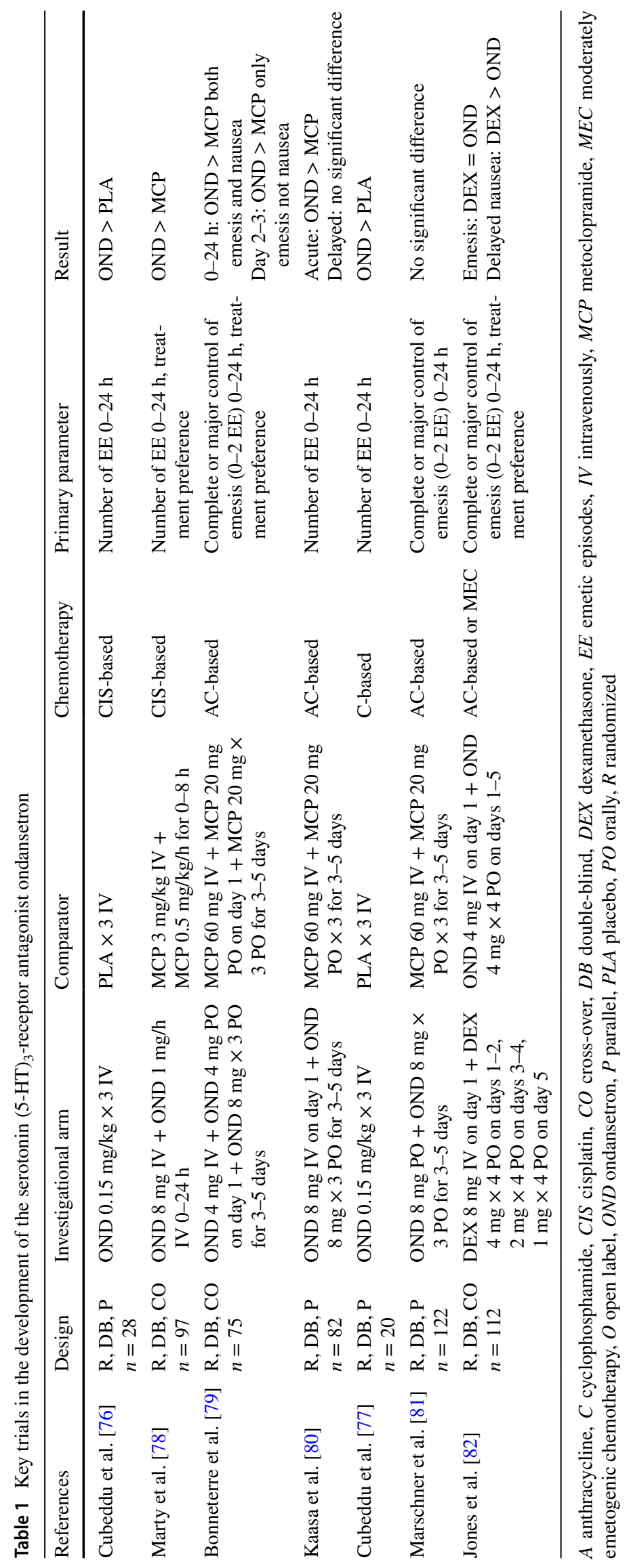


Table 2 Key trials in the development of the serotonin $(5-\mathrm{HT})_{3}$-receptor antagonist granisetron

\begin{tabular}{|c|c|c|c|c|c|c|}
\hline References & Design & Investigational arm & Comparator & Chemotherapy & Primary parameter & Result \\
\hline Warr et al. [83] & $\begin{array}{l}\mathrm{R}, \mathrm{DB}, \mathrm{P} \\
n=152\end{array}$ & GRA $80 \mu \mathrm{g} / \mathrm{kg}$ IV & $\begin{array}{r}\text { PCP } 10 \mathrm{mg} \mathrm{IV} \mathrm{+} \\
\text { DEX } 10 \mathrm{mg} \text { IV }\end{array}$ & $\begin{array}{l}\text { Dactinomycin, CIS, } \\
\text { AC, or MEC }\end{array}$ & $\begin{array}{l}\text { Severity of nausea } \\
\text { and number of EE } \\
0-24 \mathrm{~h}\end{array}$ & GRA $>$ PCP + DEX \\
\hline Warr et al. [84] & $\begin{array}{l}\mathrm{R}, \mathrm{DB}, \mathrm{P} \\
n=149\end{array}$ & GRA $80 \mu \mathrm{g} / \mathrm{kg}$ IV & $\begin{array}{l}\text { DEX } 10 \mathrm{mg} \mathrm{IV} \mathrm{+} \\
\text { DPH } 10 \mathrm{mg} \text { IV } \\
+ \text { MCP } 2 \mathrm{mg} / \mathrm{kg} \\
\text { IV every } 2 \mathrm{~h} \text { for } 5 \\
\text { doses }\end{array}$ & CIS & $\begin{array}{l}\text { Severity of nausea } \\
\text { and number of } \\
\text { patients with no } \\
\text { EE 0-24 h }\end{array}$ & $\begin{array}{l}\mathrm{GRA}=\mathrm{DEX}+\mathrm{MCP} \\
\quad+\mathrm{DPH}\end{array}$ \\
\hline Perez et al. [85] & $\begin{array}{l}\mathrm{R}, \mathrm{DB}, \mathrm{P} \\
n=1085\end{array}$ & $\begin{array}{l}\text { GRA } 2 \mathrm{mg} \mathrm{PO} \pm \\
\text { DEX }\end{array}$ & $\begin{array}{l}\text { OND } 32 \mathrm{mg} \text { IV } \pm \\
\text { DEX }\end{array}$ & $\begin{array}{l}\text { Primarily carbopl- } \\
\text { atin or C }\end{array}$ & $\begin{array}{l}\text { Total control (no } \\
\text { EE, no nausea, no } \\
\text { rescue medica- } \\
\text { tions) } 0-24 \mathrm{~h} \text { and } \\
25-48 \mathrm{~h}\end{array}$ & $\mathrm{GRA}=\mathrm{OND}$ \\
\hline Gralla et al. [86] & $\begin{array}{l}\mathrm{R}, \mathrm{DB}, \mathrm{P} \\
n=1054\end{array}$ & $\begin{array}{l}\text { GRA } 2 \mathrm{mg} \mathrm{PO} \pm \\
\text { DEX }\end{array}$ & $\begin{array}{l}\text { OND } 32 \mathrm{mg} \mathrm{IV} \pm \\
\text { DEX }\end{array}$ & CIS & $\begin{array}{l}\text { Total control (no } \\
\text { EE, no nausea, no } \\
\text { rescue medica- } \\
\text { tions) } 0-24 \mathrm{~h}\end{array}$ & $\mathrm{GRA}=\mathrm{OND}$ \\
\hline $\begin{array}{l}\text { Raftopoulos et al. } \\
\text { [87] }\end{array}$ & $\begin{array}{l}\mathrm{R}, \mathrm{DB}, \mathrm{P} \\
n=1395\end{array}$ & $\begin{array}{l}\text { Sustained-release } \\
\text { GRA } 250 \mu \mathrm{g} \text { or } \\
500 \mu \mathrm{g} \text { subcutane- } \\
\text { ously }\end{array}$ & PAL $0.25 \mathrm{mg}$ IV & HEC/MEC & $\begin{array}{l}\text { Complete response } \\
\text { (no EE, no rescue } \\
\text { medications) } \\
0-24 \mathrm{~h}\end{array}$ & $\begin{array}{l}\text { Both doses of GRA } \\
\text { noninferior to PAL }\end{array}$ \\
\hline
\end{tabular}

$A$ anthracycline, $C$ cyclophosphamide, $C I S$ cisplatin, $D B$ double-blind, $D E X$ dexamethasone, $D P H$ diphenhydramine, $E E$ emetic episodes, $G R A$ granisetron, $H E C$ highly emetogenic chemotherapy, $I V$ intravenously, $M C P$ metoclopramide, $M E C$ moderately emetogenic chemotherapy, $O N D$ ondansetron, $P$ parallel, $P A L$ palonosetron, $P C P$ prochlorperazine, $P L A$ placebo, $P O$ orally, $R$ randomized

[93] and ventricular tachycardia [94] have been published. The risk of 5- $\mathrm{HT}_{3}$-receptor antagonist-induced QTc prolongation is enhanced in older cancer patients, in particular if patients receive other agents with potential QTc prolongation risk.

The 5-HT $-\mathrm{HT}_{3}$-receptor antagonists are metabolized through different pathways. Granisetron is metabolized through the CYP450 3A4 enzyme pathway, whereas ondansetron and palonosetron are primarily metabolized through the CYP 2D6 pathway. The CYP 2D6 pathway is subject to genetic polymorphisms, meaning that patients can have zero (poor metabolizers), one (normal), two (extensive metabolizers), or three (ultrarapid metabolizers) active CYP2D6 genes. From an antiemetic point of view, the ultrarapid metabolizers are the most interesting group, because lack of antiemetic effect has been described with tropisetron and ondansetron in these patients [95]. In this case, rotation to granisetron can be useful.

\subsection{Neurokinin (NK) ${ }_{1}$-Receptor Antagonists}

Substance P (neurokinin) was discovered in 1931, but was not sequenced and purified until 1970. Three neurokinin (NK) receptors were identified in the mid-1980s, of which the $\mathrm{NK}_{1}$ receptor is involved in the emetic reflex arch. The $\mathrm{NK}_{1}$-receptor antagonists have antiemetic effect in the prevention of both acute and delayed nausea and vomiting. A large number of $\mathrm{NK}_{1}$-receptor antagonists have been investigated, but only the three marketed oral agents, aprepitant, netupitant, and rolapitant, and their intravenous formulations will be reviewed. The first clinical study with one of these agents was published in 1997 [96]. The pivotal and other important studies are summarized in Tables 4, 5 and 6.

\subsubsection{Aprepitant and Fosaprepitant}

Aprepitant and the prodrug fosaprepitant were investigated in five randomized, double-blind, phase II trials using a 5-day aprepitant regimen [97-101]. Aprepitant was inferior to the $5-\mathrm{HT}_{3}$-receptor antagonists, ondansetron and granisetron, against acute nausea and vomiting, but active in the prevention of delayed nausea and vomiting. In combination with either ondansetron plus dexamethasone or granisetron plus dexamethasone, aprepitant increased the antiemetic effect compared with placebo [101]. The phase II studies revealed a drug-drug interaction between aprepitant and dexamethasone (both metabolized through CYP3A4), resulting in an approximately $50 \%$ increase in plasma concentrations of dexamethasone [101]. Consequently, the phase III studies used a 3-day aprepitant regimen in lower dosages than used in phase II and the dosage of dexamethasone was reduced to $50-60 \%$ when combined with aprepitant. Two phase III studies in cisplatin-based chemotherapy compared ondansetron on day 1 plus dexamethasone on days 


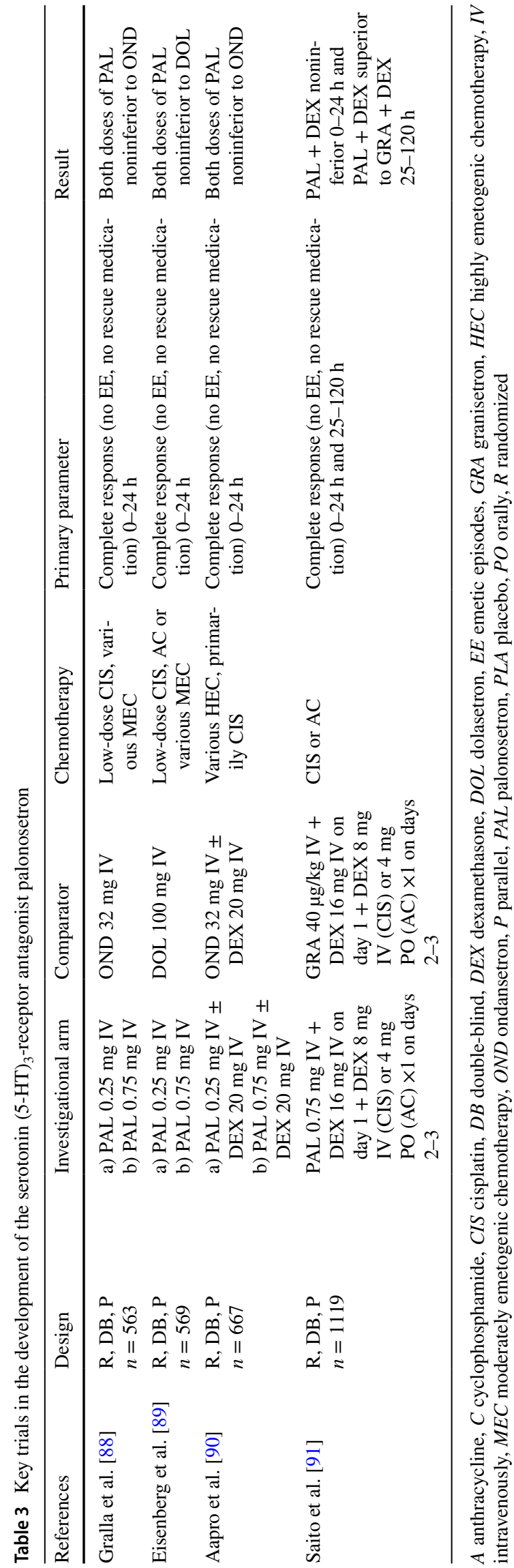

1-4 plus placebo on days 1-3 with ondansetron on day 1 plus dexamethasone on days 1-4 plus aprepitant on days 1-3 [102, 103], and a third study used the same methodology and comparison but added ondansetron on days 2-4 in the placebo arm [104]. All studies were randomized, doubleblinded, and concluded that aprepitant increased the CR rate (no emesis and no need for rescue antiemetics) both in the acute and delayed phases of CINV. Two studies in patients receiving AC-based chemotherapy [105] or AC or chemotherapy with moderate emetic risk [106], respectively, compared ondansetron on day 1 plus dexamethasone on days 1-3 plus placebo on days 1-3 with ondansetron on day 1 plus dexamethasone on days $1-3$ plus aprepitant on days $1-3$. Both concluded that aprepitant was significantly superior to placebo as concerns CR on days $1-5$ after chemotherapy. The first of these studies [105] included a multiple cycle extension part and demonstrated that the effect of aprepitant was maintained over four cycles of AC chemotherapy [107]. Finally, a large, randomized, double-blind study $(n=2.322)$ found that a single dose of fosaprepitant IV was noninferior to the standard 3-day regimen of oral aprepitant [108].

\subsubsection{Netupitant and Fosnetupitant}

Netupitant was investigated and developed in combination with palonosetron (NEPA) given as a single oral dose administered before chemotherapy. Three pivotal studies were conducted $[109,110,112]$. A dose ranging study in patients receiving cisplatin-based chemotherapy concluded that a single oral dose of NEPA plus dexamethasone on days 1-4 was superior to a single oral dose of palonosetron plus dexamethasone on days 1-4 and recommended the 300-mg netupitant dose for use in phase III trials [109].

A large, randomized, double-blind study $(n=1449)$ compared the antiemetic effect of NEPA + dexamethasone $(12 \mathrm{mg}$ ) on day 1 with palonosetron plus dexamethasone $(20 \mathrm{mg})$ on day 1 in patients receiving either AC chemotherapy or epirubicin + cyclophosphamide (EC). NEPA was superior to palonosetron in terms of CR in the delayed phase (primary parameter), but also in the acute and overall phase and as concerns no emesis and no significant nausea [110]. This study also included a multiple cycle extension in which 1286 of the 1449 patients participated. The antiemetic effect of NEPA was superior to palonosetron during all four cycles and no safety concerns were raised [111].

A phase III, randomized, double-blind study $(n=412)$ investigated a single dose of NEPA + dexamethasone (on day 1 in moderate-emetic-risk and days 1-4 in highemetic-risk patients) during multiple cycles of chemotherapy [112]. The comparator arm included aprepitant on days 1-3 plus palonosetron on day 1 and dexamethasone as in the NEPA arm. The primary parameter was safety during multiple cycles. Patients received either 


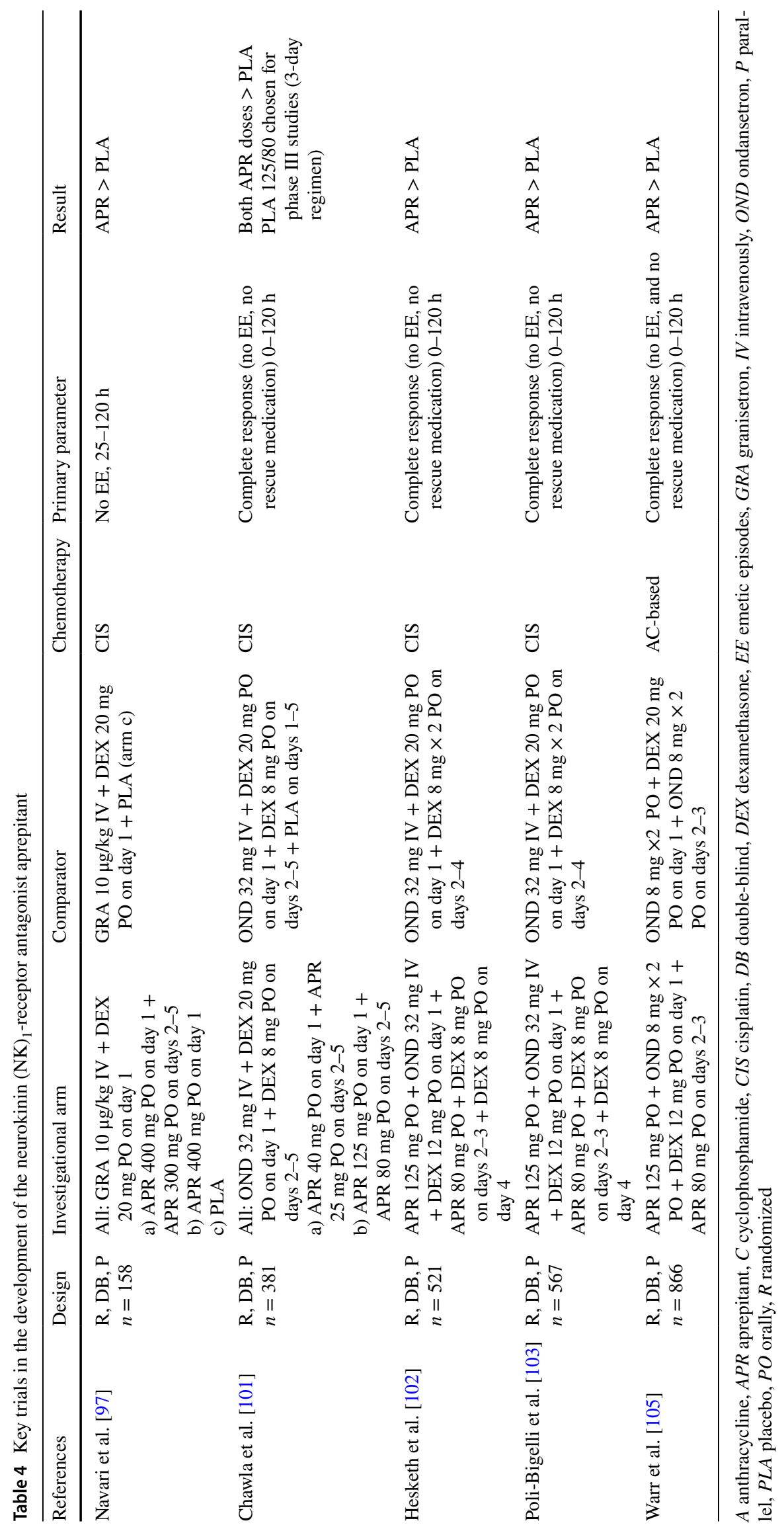


Table 5 Key trials in the development of the neurokinin $(\mathrm{NK})_{1}$-receptor antagonist netupitant

\begin{tabular}{|c|c|c|c|c|c|c|}
\hline References & Design & Investigational arm & Comparator & Chemotherapy & Primary parameter & Result \\
\hline Hesketh et al. [109] & $\begin{array}{l}\mathrm{R}, \mathrm{DB}, \mathrm{P} \\
n=677\end{array}$ & $\begin{array}{l}\text { a) NET } 100 \mathrm{mg} \text { PO } \\
\text { on day } 1 \\
\text { b) NET } 200 \mathrm{mg} \text { PO } \\
\text { on day } 1 \\
\text { c) NET } 300 \mathrm{mg} \text { PO } \\
\text { on day } 1 \\
\text { d) APR } 125 \mathrm{mg} \text { PO + } \\
\text { OND } 32 \mathrm{mg} \text { IV + } \\
\text { DEX } 12 \mathrm{mg} \text { PO on } \\
\text { day } 1+\text { APR } 80 \mathrm{mg} \\
\text { PO + DEX } 4 \mathrm{mg} \times \\
2 \text { PO on days } 2-3+ \\
\text { DEX } 4 \text { mg } \times 2 \text { PO } \\
\text { on day } 4 \\
\text { a-c: PAL } 0.5 \mathrm{mg} \text { PO } \\
+ \text { DEX } 12 \mathrm{mg} \text { PO } \\
\text { on day } 1+\text { DEX } \\
4 \text { mg } \times 2 \text { PO on } \\
\text { days } 2-4\end{array}$ & $\begin{array}{l}\text { PAL } 0.5 \mathrm{mg} \text { PO + } \\
\text { DEX } 20 \mathrm{mg} \text { PO on } \\
\text { day } 1+\text { DEX } 8 \mathrm{mg} \\
\times 2 \text { PO on days } 2-4\end{array}$ & CIS & $\begin{array}{l}\text { Complete response } \\
\text { (no EE, no rescue } \\
\text { medication) } \\
0-120 \mathrm{~h}\end{array}$ & $\begin{array}{c}\text { NET + PAL + DEX > } \\
\text { PAL + DEX + PLA } \\
\text { in all doses } \\
\text { NET } 300 \mathrm{mg} \text { chosen } \\
\text { for phase III studies }\end{array}$ \\
\hline Aapro et al. [110] & $\begin{array}{l}\mathrm{R}, \mathrm{DB}, \mathrm{P} \\
n=1449\end{array}$ & $\begin{array}{l}\text { NEPA (NET } 300 \mathrm{mg} \\
\text { + PAL 0.5 mg) PO } \\
\text { + DEX } 12 \mathrm{mg} \text { PO }\end{array}$ & $\begin{array}{l}\text { PAL } 0.5 \mathrm{mg}+\text { DEX } \\
20 \mathrm{mg} \text { PO }\end{array}$ & $\mathrm{AC}$ & $\begin{array}{l}\text { Complete response } \\
\text { (no EE, no rescue } \\
\text { medication) } \\
24-120 \mathrm{~h}\end{array}$ & $\begin{array}{l}\text { NEPA + DEX > PAL } \\
\quad+\text { DEX }\end{array}$ \\
\hline Gralla et al. [112] & $\begin{array}{l}\mathrm{R}, \mathrm{DB}, \mathrm{P} \\
n=412\end{array}$ & $\begin{array}{l}\text { NEPA (NET } 300 \mathrm{mg} \\
\text { + PAL } 0.5 \mathrm{mg} \text { ) PO } \\
\text { on day } 1+ \\
\text { HEC: DEX } 12 \mathrm{mg} \\
\text { PO on day } 1+ \\
\text { DEX } 8 \mathrm{mg} \text { PO on } \\
\text { days } 2-4 \\
\text { MEC: DEX } 12 \mathrm{mg} \\
\text { PO on day } 1\end{array}$ & $\begin{array}{l}\text { APR } 125 \mathrm{mg} \text { PO + } \\
\text { PAL } 0.5 \mathrm{mg} \text { PO on } \\
\text { day } 1+\text { APR } 80 \mathrm{mg} \\
\text { PO on days } 2-3+ \\
\text { HEC: DEX } 12 \mathrm{mg} \\
\text { PO on day } 1+ \\
\text { DEX } 8 \mathrm{mg} \text { PO on } \\
\text { days } 2-4 \\
\text { MEC: DEX } 12 \mathrm{mg} \\
\text { PO on day } 1\end{array}$ & HEC or MEC & $\begin{array}{l}\text { Safety over multiple } \\
\text { cycles }\end{array}$ & $\begin{array}{l}\text { NEPA + DEX = APR } \\
+ \text { PAL + DEX, no } \\
\text { increase in adverse } \\
\text { events over multiple } \\
\text { cycles }\end{array}$ \\
\hline
\end{tabular}

$A$ anthracycline, $A P R$ aprepitant, $C$ cyclophosphamide, $C I S$ cisplatin, $D B$ double-blind, $D E X$ dexamethasone, $E E$ emetic episodes, $H E C$ highly emetogenic chemotherapy, $I V$ intravenously, $M E C$ moderately emetogenic chemotherapy, NEPA NET + PAL, NET netupitant, $P$ parallel, $P A L$ palonosetron, $P O$ orally, $R$ randomized

a high-emetic-risk agent (e.g., cisplatin) or one of several moderate-emetic-risk agents (e.g., doxorubicin or cyclophosphamide, but not the combination). Seventyfive percent of the patients completed at least four cycles of chemotherapy and the incidence and type of adverse effects were comparable for both groups with no indication of increasing adverse events over multiple cycles.

A single infusion of fosnetupitant (IV NEPA) was compared with a single oral dose of NEPA (both combined with dexamethasone) in two randomized, double-blind trials including patients receiving a single high-emeticrisk agent [113] or AC chemotherapy [114], respectively. IV NEPA was as effective as oral NEPA and no treatmentrelated injection-site adverse effects or episodes of hypersensitivity or anaphylaxis were reported.

\subsubsection{Rolapitant}

Rolapitant was primarily investigated in a phase II dosefinding study [115] and in three randomized, double-blind, phase III trials, two in patients treated with cisplatin-based chemotherapy [116] and one in patients receiving AC/EC chemotherapy or different agents with moderate emetic risk [117].

The randomized, double-blind, dose-finding, phase II study included 454 patients all receiving cisplatin-based chemotherapy and ondansetron plus dexamethasone as antiemetic prophylaxis. Patients were randomized to one of four doses of rolapitant $(9-180 \mathrm{mg})$ or to placebo. The greatest benefit was observed with the $180-\mathrm{mg}$ dose of rolapitant, which consequently became the dose used in phase III 


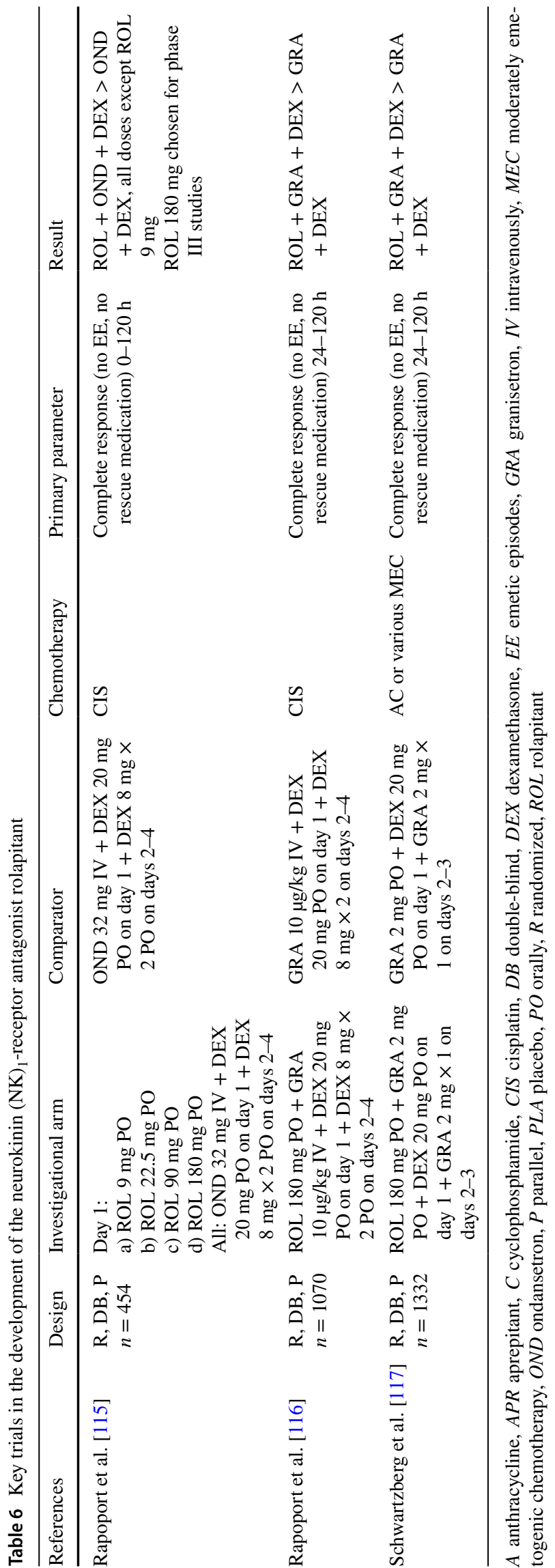

trials [115]. Rolapitant was investigated in two (HEC-1 and HEC-2) phase III studies (identical except for the location of the participating sites) in patients receiving cisplatin-based $\left(\geq 60 \mathrm{mg} / \mathrm{m}^{2}\right)$ chemotherapy. All patients received granisetron IV $(10 \mu \mathrm{g} / \mathrm{kg})$ and dexamethasone $20 \mathrm{mg}$ orally before chemotherapy plus dexamethasone $8 \mathrm{mg} \times 2$ orally on days 2-4 and were randomized to receive placebo or rolapitant $180 \mathrm{mg}$ on day 1 in addition ( $n=526$ in HEC- 1 and 544 in HEC-2). The primary endpoint was CR (defined as no emesis and no rescue antiemetics) in the delayed phase (24-120 $\mathrm{h}$ after chemotherapy). Significantly more patients in the rolapitant group had $\mathrm{CR}$ as compared with the placebo-treated patients in HEC-1, HEC-2, and in the combined analysis of both studies with no significant differences in adverse effects [116].

In a third study, 1332 patients either received AC/EC chemotherapy or different agents with moderate emetic risk such as cyclophosphamide, an anthracycline, irinotecan, oxaliplatin, or carboplatin. All patients received granisetron $2 \mathrm{mg}$ orally and dexamethasone $20 \mathrm{mg}$ orally before chemotherapy and continued with granisetron $2 \mathrm{mg}$ orally $\times 1$ on days $2-3$ and were randomized to rolapitant or placebo $\times 1$ on day 1. A significantly higher proportion of patients in the rolapitant group as compared with the placebo group had $\mathrm{CR}$ in the delayed phase (primary effect parameter) with no significant differences in adverse effects [117].

\subsubsection{Adverse Events and Potential Drug-Drug Interaction Risks}

The oral $\mathrm{NK}_{1}$-receptor antagonists are generally very well tolerated with no obvious differences in adverse event profiles. The most commonly described adverse events are headache, constipation, and hiccups, but in some of the pivotal trials these adverse events were not different in frequency or intensity compared with the placebo-control arms. Fosaprepitant (intravenous prodrug of aprepitant) has some local hypersensitivity reactions, in particular in AC patients, which is probably due to surfactant PS 80 [118]. HTX-019 (intravenous aprepitant) without surfactant has a lower incidence of hypersensitivity reactions [119] as does intravenous NEPA [118]. Intravenous rolapitant is no longer available due to a number of anaphylactic reactions.

Potential drug-drug interaction risks have been very well investigated and described for the $\mathrm{NK}_{1}$-receptor antagonists. The major difference is that aprepitant and netupitant are primarily metabolized through CYP3A4, whereas rolapitant is primarily metabolized through CYP2D6. This results in a difference in potential drug-drug interaction risks. For example, although it is recommended that the dose of dexamethasone is reduced to approximately $50 \%$ when combined with aprepitant or netupitant, this is not necessary when 
Table 7 Potential drug-drug interaction risks with the $\mathrm{NK}_{1}$-receptor antagonists aprepitant, netupitant, and rolapitant

\begin{tabular}{|c|c|c|c|}
\hline & Aprepitant & Netupitant & Rolapitant \\
\hline CYP enzymes & 3A4, 1A2, 2C9 & 3A4 & 2D6 \\
\hline Mechanism & $\begin{array}{l}\text { Inhibitor of } 3 \mathrm{~A} 4 \text { and substrate for } 3 \mathrm{~A} 4 \\
\text { and inducer of } 3 \mathrm{~A} 4 \text { and } 2 \mathrm{C} 9\end{array}$ & Inhibitor of $3 \mathrm{~A} 4$ and substrate for $3 \mathrm{~A} 4$ & Inhibitor of 2D6 and of BCRP \\
\hline No DI risk & $\begin{array}{l}\text { IV vinorelbine, docetaxel, cyclophos- } \\
\text { phamide, ondansetron, granisetron, } \\
\text { palonosetron, digoxin }\end{array}$ & $\begin{array}{l}\text { Palonosetron, digoxin, docetaxel, etopo- } \\
\text { side, cyclophosphamide, digoxin }\end{array}$ & $\begin{array}{l}\text { Dexamethasone, ranitidine, ondansetron, } \\
\text { metoclopramide, doxorubicin, epiru- } \\
\text { bicin, irinotecan, topotecan, docetaxel, } \\
\text { 5-FU, etoposide, methotrexate, keto- } \\
\text { conazole, midazolam }\end{array}$ \\
\hline PDI risks & $\begin{array}{l}\text { Dexamethasone, methylprednisolone, } \\
\text { warfarin, oral contraceptives, mida- } \\
\text { zolam, tolbutamid, ifosfamide, ritonavir } \\
\text { clarithromycin, itraconazole, phenytoin } \\
\text { rifampicin, phenobarbital, carbamaz- } \\
\text { epine, oxycodone }\end{array}$ & $\begin{array}{l}\text { Dexamethasone, methylprednisolone, } \\
\text { oral contraceptives, clarithromycin, } \\
\text { erythromycin, itraconazole, ritonavir, } \\
\text { rifampicin, carbamazepine, phenytoin, } \\
\text { phenobarbital, SSRI, SNRI }\end{array}$ & Antidepressants, thioridazine, pimozide \\
\hline
\end{tabular}

$B C R P$ breast cancer resistance protein, $C Y P$ cytochrome 450, $D I$ drug-drug interaction, $I V$ intravenously, $P D I$ potential drug-drug interaction, SNRI selective noradrenaline reuptake inhibitor, SSRI selective serotonin reuptake inhibitor

Bold indicates the primary metabolizing CYP enzyme for each antiemetic agent

used together with rolapitant. For an overview of potential drug-drug interaction risks, see Table 7.

\subsection{Others}

\subsubsection{Cannabinoids}

The cannabinoid delta-9-tetrahydrocannabinol $(\Delta-9-\mathrm{THC})$ and the synthetic cannabinoids dronabinol and nabilone were investigated in a number of trials in the 1970s and 1980s. Only a few randomized trials with small sample sizes were conducted and the majority did not comply with today's recommended trial methodology. Furthermore, adverse events such as dysphoria, euphoria, dizziness, and sedation were frequent making use difficult in older patients with cancer. These trials all used cannabinol and compared the cannabinol with antiemetics such as prochlorperazine and other dopamine-receptor antagonists no longer recommended as standard antiemetic therapy.

Meiri and coworkers compared the antiemetic effect of dronabinol, ondansetron, and the combination with placebo in patients receiving moderate- or high-emetic-risk chemotherapy $(n=61)$. Unfortunately, the study was prematurely closed and no relevant conclusions can be drawn [120].

A recent phase II, randomized, double-blind, placebocontrolled, crossover study $(n=72)$ investigated the antiemetic effect of an extract of THC and cannabidiol (CBD) in patients with refractory chemotherapy-induced nausea and/or vomiting [121]. The authors concluded that the addition THC/CBD to standard antiemetics resulted in less nausea and vomiting but also in additional adverse events. The median age of patients in this trial was only 55 years, meaning that more adverse events could be expected in real-life patients with cancer who are 10-15 years older. Due to the modest antiemetic effect and the high risk of adverse effects, interest in investigating cannabinoids in combination with modern antiemetics has been limited. The National Comprehensive Cancer Network (NCCN) antiemetic guidelines include dronabinol as an antiemetic in breakthrough nausea and vomiting not responding to other antiemetics, but no other evidence-based guidelines recommend the use of cannabinoids for CINV [5], and a recent systematic review concluded that although there is some neurophysiological support for the use of cannabinoids in CINV, this is not supported by randomized clinical trials [122].

\subsubsection{Olanzapine}

Olanzapine is approved as an antipsychotic drug targeting multiple receptors such as $\mathrm{D}_{1}-\mathrm{D}_{4}, 5-\mathrm{HT}_{2 \mathrm{~A}}, 5-\mathrm{HT}_{2 \mathrm{C}}, 5-\mathrm{HT}_{3}$, 5- $\mathrm{HT}_{6}$, histamine $\mathrm{H}_{1}, \alpha_{1}$-adrenergic, acetylcholine, and muscarinic receptors [123] and has been investigated as an antiemetic in a number of phase II [124-127] and phase III trials [128-130] and addressed in a number of scientific reviews [131, 132].

In an open-designed, phase III study $(n=241)$, chemotherapy-naïve patients were treated with cisplatin-based $(\geq$ $70 \mathrm{mg} / \mathrm{m}^{2}$ ) or AC chemotherapy and all received palonosetron plus dexamethasone as antiemetic prophylaxis on day 1 . Patients were randomized to receive either olanzapine $10 \mathrm{mg}$ once daily on days 1-4 (OPD) or aprepitant on days 1-3 plus dexamethasone on days 2-4 (APD) as additional antiemetic prophylaxis. No significant difference was found in CR (no emesis and no rescue antiemetics $0-120 \mathrm{~h}$ after initiation of 
chemotherapy), but nausea was better controlled with the OPD regimen [128].

A randomized, double-blind study $(n=380)$ in chemotherapy-naïve patients receiving cisplatin-based $(\geq 70 \mathrm{mg}$ / $\left.\mathrm{m}^{2}\right)$ or AC chemotherapy compared olanzapine $(10 \mathrm{mg} \times 1$ orally on days 1-4) with placebo, both in combination with aprepitant (or fosaprepitant) plus a 5- $\mathrm{HT}_{3}$-receptor antagonist plus dexamethasone [129]. Nausea prevention (the primary endpoint) was significantly improved by olanzapine, as were the CR rates (no emesis and no rescue antiemetics) 0-24 h, 25-120 h and 0-120 h after initiation of chemotherapy, respectively [129]. Some patients had increased sedation with olanzapine, which was severe in 5\%. Again, the median age in this trial was only 57 years (approximately 10 years younger than real-life patients), meaning that the risk of sedation could be higher in older real-life patients.

A recent, randomized, double-blind trial $(n=710)$ in chemotherapy-naïve patients treated with cisplatin-based chemotherapy $\left(\geq 50 \mathrm{mg} / \mathrm{m}^{2}\right)$ demonstrated that a 5-mg dose of olanzapine (once daily on days 1-4) is also superior to placebo (both combined with aprepitant, palonosetron and dexamethasone) [130].

Based on these three trials, olanzapine is now recommended as an option in evidence-based antiemetic guidelines [5]. Besides sedation, postural hypotension, fatigue, and anticholinergic effects have been described.

\subsubsection{Evidence-Based Prophylaxis of Chemotherapy-Induced Nausea and Vomiting}

Several guidelines have been published, but the most frequently used are the Multinational Association of Supportive Care in Cancer/European Society for Medical Oncology (MASCC/ESMO) [133, 134], the American Society of Clinical Oncology (ASCO) [135], and the NCCN [136] guidelines. The MASCC/ESMO and ASCO guidelines are strictly evidence-based, whereas the NCCN guidelines are more pragmatic based on evidence but also on experts' opinion. There are only minor differences between the guideline recommendations; primarily, the NCCN guidelines have more detailed recommendations and a more extended indication for some antiemetics than the others. The MASCC/ ESMO and ASCO guidelines are updated when new data have been published. The NCCN guidelines are updated once every year. None of the guidelines have specific recommendations for older patients receiving chemotherapy, although the NCCN guidelines do have some pharmacological considerations.

Guidelines provide recommendations for the prophylaxis of acute and delayed emesis induced by single-day chemotherapy and multiple-day chemotherapy. Recommendations are also provided for breakthrough nausea and vomiting and for anticipatory nausea and vomiting. Recommendations are given for both adult and pediatric patients. Below is a summary (adults only) of the recommendations for the prophylaxis of acute and delayed CINV induced by single-day IV chemotherapy or by multiple-day IV chemotherapy with moderate- and/or high-emetic-risk IV chemotherapy on day 1 only.

\subsection{Minimal Emetic Risk ( $<10 \%)$}

None of the guidelines recommended routine antiemetic prophylaxis. Patients should have access to rescue antiemetics such as a $\mathrm{D}_{2}$-receptor antagonist, a 5- $\mathrm{HT}_{3}$-receptor antagonist or a corticosteroid.

\subsection{Low Emetic Risk (10-30\%)}

A dopamine-receptor antagonist (MASCC/ESMO, NCCN), a serotonin-receptor antagonist (MASCC/ESMO, ASCO, NCCN) or dexamethasone (MASCC/ESMO, ASCO, NCCN) is recommended for prophylaxis in the first $24 \mathrm{~h}$ after chemotherapy. None of the guidelines recommend routine antiemetics for delayed CINV protection.

\subsection{Moderate Emetic Risk (30-90\%)}

\subsubsection{Carboplatin}

Patients treated with carboplatin $\geq$ AUC $4 \mathrm{mg} / \mathrm{mL} / \mathrm{min}$ are recommended a three-drug combination of an $\mathrm{NK}_{1}$-receptor antagonist, a 5- $\mathrm{HT}_{3}$-receptor antagonist, and dexamethasone (day 1). The NCCN guidelines consider carboplatin a drug with high emetic risk, although the risk of emesis in the first $24 \mathrm{~h}$ after carboplatin is < 90\% [137]. In patients receiving the above three-drug combination only, rescue antiemetics are recommended after the first $24 \mathrm{~h}$.

\subsubsection{Other than Carboplatin}

Patients treated with moderate-emetic-risk chemotherapy other than carboplatin $\geq 4 \mathrm{mg} / \mathrm{mL} / \mathrm{min}$ are recommended a two-drug combination of a 5- $\mathrm{HT}_{3}$-receptor antagonist and dexamethasone on day 1 (MASCC/ESMO, ASCO, NCCN). Patients treated with cyclophosphamide, doxorubicin/epirubicin, or oxaliplatin (MASCC/ESMO, ASCO, NCCN) and other moderate-emetic-risk agents known to cause delayed nausea and vomiting (ASCO, NCCN) may be offered dexamethasone on days $2-3$. The NCCN guidelines also suggest an $\mathrm{NK}_{1}$-receptor antagonist or olanzapine (both as part of a three-drug regimen with a 5- $\mathrm{HT}_{3}$-receptor antagonist and 
dexamethasone) as an option on day 1 and as a single agent on days $2-3$.

\subsection{High Emetic Risk (> 90\%)}

The ASCO guidelines recommend a four-drug regimen of

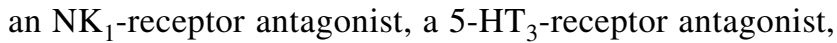
dexamethasone, and olanzapine for prophylaxis of CINV induced by a single agent (cisplatin and other) high-emeticrisk chemotherapy or induced by the AC combination (day 1). It is recommended to continue dexamethasone and olanzapine on days $2-4$ in cisplatin-based chemotherapy and to continue olanzapine on days 2-4 in AC chemotherapy. If the $\mathrm{NK}_{1}$-receptor antagonist chosen is aprepitant, aprepitant should be continued on days 2-3. Both MASCC and NCCN recommend the four-drug regimen as well, but also suggest two different three-drug regimens as alternative options (palonosetron and dexamethasone combined with olanzapine [day 1] or a $5-\mathrm{HT}_{3}$-receptor antagonist and dexamethasone combined with an $\mathrm{NK}_{1}$-receptor antagonist [day 1], with the same treatment on days $2-4$ or days $2-3$ as described above).

\section{Conclusion and Future Perspectives}

Evidence-based recommendations for the prophylaxis of CINV have been optimized during the past 40 years. Today, vomiting can be prevented in the majority of patients, whereas nausea remains a significant problem. This is due to the fact that $5-\mathrm{HT}_{3}$-receptor antagonists and $\mathrm{NK}_{1}$-receptor antagonists are very effective in the prophylaxis of emesis, but only have limited effect against nausea. The most effective anti-nausea agents seem to be those targeting multiple receptors, such as olanzapine.

None of the guidelines have specific recommendations for older patients receiving chemotherapy. Young age is a risk factor for CINV, meaning that older patients have a lower risk of CINV than younger patients provided they receive the same kind of chemotherapy and antiemetic prophylaxis. Our knowledge about the risk of CINV in older patients is limited, because randomized clinical trials (RCTs) do not represent real-life patients. Patients included in RCTs are younger, they have less comorbidity and use a lower number of medications than real-life patients. In a review of $>260,000$ patients included in 302 trials published on the ClinicalTrials.gov website in the period 1994-2015, the average age of included patients was almost 7 years younger than the average age of the background cancer population in the same period [138]. The average number of exclusion criteria in industry-sponsored trials is 49 [139] and $91 \%$ of trials have exclusion criteria with respect to physical function and $85 \%$ with respect to organ function [140]. This is also a fact as concerns RCTs in CINV.
Table 8 Age of patients included in industry-funded pivotal trials and largest post-marketing studies in Tables 1, 2, 3, 4, 5 and 6

\begin{tabular}{lll}
\hline References & \multicolumn{2}{l}{ Age, years; median or mean (range) } \\
\cline { 2 - 3 } & Investigational arm & Standard/placebo arm \\
\hline Marty et al. [78] & Median 57 (29-69) & Median 57 (29-69) \\
Bonneterre et al. [79] & No data & No data \\
Kaasa et al. [80] & Median 58 (19-80) & Median 58 (19-80) \\
Marschner et al. [81] & Median 55 (28-79) & Median 53 (29-77) \\
Warr et al. [84] & Median 57 (no data) & Median 55 (no data) \\
Perez et al. [85] & Mean 55 (18-87) & Mean 56 (21-94) \\
Gralla et al. [86] & Mean 62 (19-87) & Mean 62 (20-88) \\
Gralla et al. [88] & Mean 56 (no data) & Mean 55 (no data) \\
Eisenberg et al. [89] & Mean 53 (no data) & Mean 54 (no data) \\
Aapro et al. [90] & Mean 53 (no data) & Mean 51 (no data) \\
Saito et al. [91] & Mean 58 (no data) & Mean 58 (no data) \\
Navari et al. [97] & Mean 64 (no data) & Mean 60 (no data) \\
Chawla et al. [101] & Mean 56 (no data) & Mean 54 (no data) \\
Hesketh et al. [102] & Mean 59 (no data) & Mean 58 (no data) \\
Poli-Bigelli et al. [103] & Mean 54 (no data) & Mean 53 (no data) \\
Warr et al. [105] & Mean 53 (no data) & Mean 52 (no data) \\
Hesketh et al. [109] & Median 53 (19-77) & Median 55 (no data) \\
Aapro et al. [110] & Median 54 (22-79) & Median 54 (no data) \\
Gralla et al. [112] & Median 57 (27-76) & Median 59 (no data) \\
Rapoport et al. [115] & Median 56 (20-75) & Median 54 (18-77) \\
Rapoport et al. [116] & Median 59 (21-86) & Median 59 (18-90) \\
Schwartzberg et al. & Median 58 (22-86) & Median 56 (22-88) \\
[117] & & \\
\hline & & \\
\hline
\end{tabular}

In Table 8, median or mean age is listed for patients included in the pivotal and largest post-marketing studies of 5- $\mathrm{HT}_{3}$-receptor antagonists and $\mathrm{NK}_{1}$-receptor antagonists (see also Tables 1, 2, 3, 4, 5 and 6). In all but two of the 21 trials with data of median (or mean) age, the median (mean) age is $<60$ years. As in other RCTs, this is 5-10 years younger than in real-life patients. Because of the younger age of patients in CINV RCTs as compared with real-life patients, one could speculate that the emetic risk of chemotherapy in the RCTs is higher than in real-life. Therefore, some older patients may have been over treated with antiemetics.

As previously mentioned, a number of studies have investigated steroid-sparing regimens comparing dexamethasone on day 1 of chemotherapy only with $2-4$ days of dexamethasone [141, 142]. With cisplatin-based chemotherapy as an exception, it seems that dexamethasone on day 1 is as good as several days of dexamethasone. In cisplatin-based chemotherapy, no clear-cut conclusion can be drawn from studies currently available [143, 144]. In patients receiving immunotherapy, the lowest effective dose of dexamethasone is recommended [145] and the lowest effective dose is also recommended for prophylaxis 
1. Define the emetic risk potential of the patient's chemotherapy

2. Define the antiemetic guideline recommendation accordingly

\section{Check for organ deficiencies}

a) Intestinal absorption - if compromised (e.g. nausea, short bowel syndrome) use iv antiemetics)

b) Renal function

c) Liver function

\section{Check for comorbidity}

a) Cardiovascular disease primarily arrhythmias and QTc prolongation

b) If QTc prolongation is present be careful when prescribing $5-\mathrm{HT}_{3}$-receptor antagonists and follow-up

c) Diabetes - consider to avoid prescription of steroids

\section{Check for polypharmacy}

a) Check all different medications for potential drug-drug interactions with antiemetics

b) Choose antiemetics with the lowest risk of a drug-drug interaction with the current medication.

c) Choose antiemetics with the lowest risk of a drug-drug interaction with the antineoplastic therapy (AT)

\section{Check for potential lack of patient compliance}

a) Any sign of dementia?

b) Use the most simple antiemetic regimen, preferably one dose of each antiemetic before AT

\section{Modify the antiemetic guideline recommendation if necessary}

a) If dexamethasone is part of the regimen, consider to use only one dose

b) If olanzapine is part of the antiemetic regimen use a $5 \mathrm{mg}$ dose and limit the number of days

c) If an $\mathrm{NK}_{1}$-receptor antagonist is part of the antiemetic regimen use a single dose of a long-acting agent.

d) If a 5- $\mathrm{HT}_{3}$-receptor antagonist is part of the regimen, use a single dose, check for constipation, follow-up.

\section{Follow-up (effect and tolerability) at the next chemotherapy cycle and modify if necessary}

Fig. 1 Flow diagram for prescribing antiemetic prophylaxis of CINV in older cancer patients 
of CINV during the COVID-19 pandemic [146]. This is of special interest for older cancer patients, because the single-day dexamethasone strategy enables the entire antiemetic prophylaxis to be administered before chemotherapy with no need for routine antiemetics in the subsequent days, resulting in optimal compliance. For example, for the prophylaxis of carboplatin-induced nausea and vomiting, guidelines recommend the combination of single doses of a $5-\mathrm{HT}_{3}$-receptor antagonist, dexamethasone, and one of the long-acting $\mathrm{NK}_{1}$-receptor antagonists (netupitant or rolapitant) as an option [133].

Also, when using olanzapine for prophylaxis of CINV in older cancer patients, the lowest effective dose should be used. Studies confirm that olanzapine $5 \mathrm{mg}$ is superior to placebo [130], but no large RCT has directly compared $5 \mathrm{mg}$ and $10 \mathrm{mg}$ of olanzapine. In older patients, it seems reasonable to start with the $5-\mathrm{mg}$ dose of olanzapine to avoid the risk of severe sedation.

Other considerations should be taken into account when prescribing antiemetics to older patients with cancer. Figure 1 shows a flow diagram with these considerations and recommendations for prescribing antiemetics to older patients.

Future trials should investigate deprescription of antiemetics in older patients in order to reduce the risk of drug-drug interactions and to reduce costs. A metaanalysis of four previously published studies concluded that the $\mathrm{NK}_{1}$-receptor antagonist, aprepitant, increased the antiemetic effect of a 5- $\mathrm{HT}_{3}$-receptor antagonist plus dexamethasone in patients aged $65+$ years as compared with placebo, but in fact this difference was only statistically significant in one of the four trials [147]. Another post-hoc subanalysis of three previously published trials concluded that NEPA is effective and well tolerated in older patients receiving moderately or highly emetogenic chemotherapy [148]. Since our knowledge of the use of $\mathrm{NK}_{1}$-receptor antagonists in older cancer patients is limited to post-hoc subanalysis of previously published studies, we need a welldesigned prospective phase II trial that limits inclusion to older patients with cancer (e.g., $70+$ years old) receiving emetogenic chemotherapy and investigates deprescription of antiemetics (two antiemetics instead of three) and includes a preplanned subanalysis of patients with other emetogenic low risk factors (e.g., men vs women). In case of promising phase II results, a phase III RCT should follow comparing two versus three antiemetics in a double-blind noninferiority design. If non-inferiority (of two antiemetics versus three) is confirmed, guidelines should be updated accordingly including specific recommendations for older patients.

\section{Declarations}

Funding Not applicable.
Conflicts of interest/Competing interests Dr Herrstedt received an honorarium from SOBI in 2019.

Availability of data and material Not applicable.

Code availability Not applicable.

Authors' contributions Dr Herrstedt had the idea for the review. All authors contributed to the literature search and data analysis. Dr Herrstedt drafted the manuscript and all authors commented on previous versions of the manuscript. All authors read and approved the final manuscript.

\section{References}

1. Sung H, Ferlay J, Siegel RL, Laversanne M, Soerjomataram I, Jemal A, Bray F. Global cancer statistics 2020: GLOBOCAN estimates of incidence and mortality worldwide for 36 cancers in 185 countries. CA Cancer J Clin. 2021;71:209-49.

2. Ferlay J, Ervik M, Lam F, Colombet M, Mery L, Piñeros M, Znaor A, Soerjomataram I, Bray F. Global cancer observatory: cancer today. Lyon, France: International Agency for Research on Cancer. 2020. https://gco.iarc.fr/today. Accessed 01 July 2021.

3. Arnold M, Rutherford MJ, Bardot A, Ferlay J, Andersson TML, Myklebust TA, et al. Progress in cancer survival, mortality, and incidence in seven high-income countries 1995-2014 (ICBP SURVMARK-2): a population-based study. Lancet Oncol. 2019;20:1493-505.

4. Jørgensen TL, Hallas J, Land LH, Herrstedt J. Comorbidity and polypharmacy in elderly cancer patients: the significance on treatment outcome and tolerance. J Geriatr Oncol. 2010;1:87-102.

5. Herrstedt J. The latest consensus on antiemetics. Curr Opin Oncol. 2018;30:233-9.

6. Dranitsaris G, Molassiotis A, Clemons M, et al. The development of a prediction tool to identify cancer patients in high risk of chemotherapy-induced nausea and vomiting. Ann Oncol. 2018;28:1260-7.

7. Jordan K, Chan A, Gralla RJ, Jahn F, Rapoport B, Warr D, et al. 2016 updated MASCC/ESMO consensus recommendations: emetic risk classification and evaluation of the emetogenicity of antineoplastic agents. Support Care Cancer. 2017;25:271-5.

8. Ajeet G, Klepin HD, Feng T, Tew WP, Mohile SG, Owusu C, et al. Predictors of chemotherapy dose reduction at first cycle in patients aged 65 years and older with solid tumors. J Geriatr Oncol. 2015;6:133-40.

9. Mizuno M, Hiura M, Kikkawa F, Numa F, Yaegashi N, Narahara $\mathrm{H}$, et al. A prospective observational study on chemotherapyinduced nausea and vomiting (CINV) in patients with gynaecologic cancer by the CINV Study Group of Japan. Gynecol Oncol. 2016;140:559-64.

10. Hesketh PJ, Aapro M, Street JC, Carides AD. Evaluation of risk factors predictive of nausea and vomiting with current standardof-care antiemetic treatment: analysis of two phase III trials of aprepitant in patients receiving cisplatin-based chemotherapy. Support Care Cancer. 2010;18:1171-7.

11. Daiki T, Suzuki K, Kawasaki Y, Goto K, Matsui R, Seki N, et al. Risk factors associated with chemotherapy-induced nausea and vomiting in the triplet antiemetic regimen including palonosetron or granisetron for cisplatin-based chemotherapy: analysis of a randomized, double-blind controlled trial. Support Care Cancer. 2019;27:1139-47. 
12. Rha SY, Park Y, Song SK, Lee CE, Lee J. Controlling chemotherapy-induced nausea requires further improvement: symptom experience and risk factors among Korean patients. Support Care Cancer. 2016;24:3379-89.

13. Hayashi T, Shimokawa M, Matsuo K, Miyoshi T, Toriyama Y, Yokota C. Risk factors for delayed chemotherapy-induced nausea and vomiting with low-emetic-risk chemotherapy: a prospective, observational, multicenter study. Cancer Manag Res. 2018;10:4249-55.

14. Furukawa N, Akasaka J, Shigemitsu A, Sasaki Y, Nagai A, Kawaguchi R, et al. Evaluation of the relation between patient characteristics and the state of chemotherapy-induced nausea and vomiting in patients with gynecologic cancer receiving paclitaxel and carboplatin. Arch Gynecol Obstet. 2014;289:859-64.

15. Tsuji Y, Baba H, Takeda K, Kobayashi M, Oki E, Gotoh M, et al. Chemotherapy-induced nausea and vomiting (CINV) in 190 colorectal cancer patients: a prospective registration study by the CINV study group of Japan. Expert Opin Pharmacother. 2017;18:753-8.

16. Aapro M, Molassiotis A, Dicato M, Peláez I, Rodríguez-Lescure Á, Pastorelli D, et al. The effect of guideline-consistent antiemetic therapy on chemotherapy-induced nausea and vomiting (CINV): the Pan European Emesis Registry (PEER). Ann Oncol. 2012;23:1986-92.

17. ESMO Handbook of Cancer in the Senior Patient. In: Matti SA, Dirk S. editors. 2nd ed. 2015.

18. Wildiers H, Heeren P, Puts M, et al. International Society of Geriatric Oncology Consensus on geriatric asessment in older people with cancer. J Clin Oncol. 2014;32:2595-603.

19. Soenen S, Rayner CK, Jones KL, Horowitz M. The ageing gastrointestinal tract. Curr Opin Nutr Metab Care. 2016;19:12-8.

20. Tveito M, Smith RL, Molden E, et al. Age impacts olanzapine exposure differently during use of oral versus long-acting injectable formulations: an observational study including 8,288 patients. J Clin Psychopharmacol. 2018;38:570-6.

21. Weinstein JR, Anderson S. The aging kidney: physiological changes. Adv Chronic Kidney Dis. 2010;17:302-7.

22. Eriksen BO, Stefansson VTN, Jenssen TG, Mathisen UD, Schei $\mathrm{J}$, Solbu MD, et al. Elevated blood pressure is not associated with accelerated glomerular filtration rate decline in the general nondiabetic middle-aged population. Kidney Int. 2016;90:404-10.

23. Peterson LL, Hurria A, Feng T, et al. Association betweeen renal function and chemotherapy-related toxicity in older adults with cancer. J Geriatr Oncol. 2017;8:96-1010.

24. Strait JB, Lakatta EG. Aging-associated cardiovascular changes and their relationship to heart failure. Heart Fail Clin. 2012;8:143-64.

25. Brygger L, Herrstedt J. 5-Hydroxytryptamine 3 receptor antagonists and cardiac side effects. Expert Opin Drug Saf. 2014;13:1407-22.

26. Hartsock RJ, Smith EB, Petty CS. Normal variants with aging of the amount of hematopoietic tissue in bone marrow from the anterior iliac crest. A study made from 177 cases of sudden death examined by necropsy. Am J Clin Pathol. 1965;43:326-31.

27. Lyman GH, Abella E, Pettengell R. Risk factors for febrile neutropenia among patients with cancer receiving chemotherapy: a systematic review. Crit Rev Oncol Hematol. 2014;90:190-9.

28. Guida JL, Agurs-Collins T, Ahles TA, Campisi J, Dale W, Demark-Wahnefried W, et al. Stategies to prevent or remediate cancer and treatment-related aging. J Natl Cancer Inst. 2021;113:112-22.

29. Chudiak A, Uchmanowicz I, Mazur G. Relation between cognitive impairment and treatment adherence in elderly hypertensive patients. Clin Intervent Aging. 2018;13:1409-18.
30. Ofori-Asenso R, Chin KL, Curtis AJ, Zomer E, Zoungas S, Liew D. Recent patterns of multimorbidity among older adults in highincome countries. Popul Health Manag. 2019;22:127-37.

31. Jørgensen TL, Hallas J, Friis S, Herrstedt J. Comorbidity in elderly cancer patients in relation to overall and cancer-specific mortality. Br J Cancer. 2012;106:1353-60.

32. Koo MM, Swann R, McPhail S, Abel GA, Renzi C, Rubin GP, et al. The prevalence of chronic conditions in patients diagnosed with one of 29 common and rarer cancers: a crosssectional study using primary care data. Cancer Epidemiol 2020;69:101845. https://doi.org/10.1016/j.canep.2020.101845.

33. Charlson ME, Pompei P, Ales KL, MacKenzie CR. A new method of classifying prognostic comorbidity in longitudinal studies: development and validation. J Chronic Dis. 1987;40:373-83.

34. Linn BS, Lin MW, Gurel L. Cumulative illness rating scale. J Am Geriatr Soc. 1968;16:622-6.

35. Masnoon N, Shakib S, Ellett LK, Caughey GE. What is polypharmacy? A systematic review of definitions. BMC Geriatr. 2017; 17:230.

36. Corbett T, Bridges J. Multimorbidity in older adults living with and beyond cancer. Curr Opin Support Palliat Care. $2019 ; 13: 220-4$.

37. Korc-Grodzicki B, Boparai MK, Lichtman SM. Prescribing for older patients with cancer. Clin Adv Hematol Oncol. 2014;12:309-18.

38. Jørgensen TL, Herrstedt J, Friis S, Hallas J. Polypharmacy and drug use in elderly Danish cancer patients during 1996-2006. J Geriatr Oncol. 2012;3:33-40.

39. Beinse G, Reitter D, Segaux L, Carvahlo-Verlinde M, Rousseau $\mathrm{B}$, Tournigand C, et al. Potential drug-drug interactions and risk of umplanned hospitalization in older patients with cancer: a survey of the prospective ELCAPA (ELderly CAncer PAtients) cohort. J Geriatr Oncol. 2020;11:586-92.

40. Carlsson A, Lindqvist M, Magnusson T. 3,4-Dihydroxyphenylalanine and 5-hydroxytryptophane as reserpine antagonists. Nature. 1957;180:1200.

41. Shen WW, Baig MS, Sata LS, Hofstatter L. Dopamine receptor supersensitivity and the chemoreceptor trigger zone. Biol Psychiatry. 1983;18:917-21.

42. Yoshida N, Yoshikawa T, Hosoki K. A dopamine D3 receptor agonist, 7-OH-DPAT, causes vomiting in the dog. Life Sci. 1995;57:347-50.

43. Herrstedt J, Summers Y, Jordan K, Von Pawel J, Jakobsen AH, Ewertz M, Chan S, Naik JD, Karthaus M, Dubey S, Davis R, Fox GM. Amisulpride prevents nausea and vomiting associated with highly emetogenic chemotherapy: a randomized, double-blind, placebo-controlled, dose-ranging trial. Support Care Cancer. 2019;27:2699-705.

44. Moertel C, Reitemeier RJ. Controlled clinical studies of orally administered antiemetic drugs. Gastroenterology. 1969;57:262-8.

45. Moertel C, Reitemeier RJ. Controlled studies of metopimazine for the treatment of nausea and vomiting. J Clin Pharmacol. 1973;13:283-7.

46. Herrstedt J, Sigsgaard T, Boesgaard M, Jensen TP, Dombernowsky P. Ondansetron plus metopimazine compared with ondansetron alone in patients receiving moderately emetogenic chemotherapy. N Engl J Med. 1993;328:1076-80.

47. Herrstedt J, Sigsgaard T, Handberg J, Schousboe BMB, Hansen M, Dombernowsky P. Randomized, double-blind comparison of ondansetron versus ondansetron plus metopimazine as antiemetic prophylaxis during platinum-based chemotherapy in patients with cancer. J Clin Oncol. 1997;15:1690-6.

48. Jolliet P, Nion S, Allain-Veyrac G, Tilloy-Fenart L, Vanuxeem D, Berezowsky V, Cecchelli R. Evidence of lowest brain penetration of an antiemetic drug, metopimazine, compared to domperidone, 
metoclopramide and chlorpromazine, using an in vitro model of the blood-brain barrier. Pharmacol Res. 2007;56:11-7.

49. Frytak S, Moertel CG, Eagan RT, O'Fallon JR. A doubleblind comparison of metoclopramide and prochlorpearzine as antiemetics for platinum therapy. Proc Am Soc Clin Oncol. 1981;22:421.

50. Olver IN, Wolf M, Laidlaw C, Bishop JF, Cooper IA, Matthews J, Smith R, Buchanan L. A randomised double-blind study of high-dose intravenous prochlorperazine versus high-dose metoclopramide as antiemetics for cancer chemotherapy. Eur J Cancer. 1992;28A:1798-802.

51. Sallan SE, Cronin C, Zelen M, Zinberg NE. Antiemetics in patients receiving chemotherapy for cancer: a randomized comparison of delta-9-tetrahydrocannabinol and prochlorperazine. N Engl J Med. 1980;302:135-8.

52. Roscoe JA, Heckler CE, Morrow GR, Mohile SG, Dakhil SR, Wade JL, Kuebler JP. Prevention of delayed nausea: A University Rochester Cancer Center Community Clinical Oncology Program Study of patients receiving chemotherapy. J Clin Oncol. 2012;30:3389-95.

53. Justin-Besancon L, Laville C. Action antiémétique du métoclopramide vis-à-vis de l'apomorphine et de l'hydergine. CR Soc Biol (Paris). 1964;158:723.

54. Pinder RM, Brogden RN, Sawyer R, Speight TM, Avery GS. Metoclopramide: a review of its pharmacological properties and clinical use. Drugs. 1976;12:81-131.

55. Cunningham D, Evans C, Gazet JC, Ford H, People A, Dearling J, Chappell D, Coombes C. Comparison of antiemetic efficacy of domperidone, metoclopramide, and dexamethasone in patients receiving outpatient chemotherapy regimens. BMJ. 1987;295(6592):250.

56. Gralla RJ, Itri L, Pisko SE, Squillante AE, Kelsen DP, Braun DW, Bordin LA, Braun TJ, Young CW. Antiemetic efficacy of high-dose metoclopramide: randomized trials with placebo and prochlorperazine in patients with chemotherapy-induced nausea and vomiting. N Engl J med. 1981;305:905-9.

57. Warrington PS, Allan SG, Cornbleet MA, MacPherson JS, Smyth JF, Leonard RCF. Optimising antiemesis in cancer chemotherapy: efficacy of continuous versus intermittent infusion of high dose metoclopramide in emesis induced by cisplatin. BMJ. 1986;293:1334-7.

58. Kris MG, Gralla RJ, Clark RA, Tyson LB, Groshen S. Antiemetic control and prevention of side effects of antiemetic cancer therapy with lorazepam or diphenhydramine when used in combination with metoclopramide and dexamethasone. Cancer. 1987;60:2816-22.

59. Roila F, Tonato M, Basurto C, Picciafuoco M, Bracarda S, Donati D, Malacarne P, Monici L, Di Costanzo F, Patoia L, Ballatori E, Tognoni G, Del Favero A. Protection from nausea and vomiting in cisplatin-treated patients: high-dose metoclopramide combined with methylprednisolone versus metoclopramide combined with dexamethasone and diphenhydramine: a study of the Italian Oncology Group for Clinical Research. J Clin Oncol. 1989;7:1693-700.

60. Fozard JR, Mobarok ALIA. Blockade of neuronal tryptamine receptors by metoclopramide. Eur J Pharmacol. 1978;49:109-12.

61. Fozard JR. MDL 72222, a potent and highly antagonist at neuronal 5-hydroxytryptamine receptors. Naunyn Schmiedebergs Arch Pharmacol. 1984;326:36-44.

62. Miner WD, Sanger GJ. Inhibition of cisplatin-induced vomiting by selective 5-hydroxytryptamine $\mathrm{M}$ receptor antagonism. $\mathrm{Br}$ J Pharmacol. 1986;88:497-9.

63. Costall B, Domeney AM, Naylor RJ, Tattersall FD. 5-hydroxytryptamine M-receptor antagonism to prevent cisplatin-induced emesis. Neuropharmacol. 1986;25:959-61.
64. Joss RA, Goldhirsch A, Brunner KW, Galeazzi RL. Sudden death in cancer patients after high-dose domperidone. Lancer. 1982;1:1019.

65. Roussak JB, Carey P, Parry H. Cardiac arrest after treatment with intravenous domperidone. BMJ. 1984;8:1579.

66. Giaccone G, Bertetto O, Calciati A. Two sudden deaths during prophylactic antiemetic treatment with high doses of domperidone and methylprednisolone. Lancet. 1984;8:1336.

67. Osborne RJ, Slevin ML, Hunter RW, Hamer J. Cardiotoxicity of intravenous domperidone. Lancet. 1985;17:385.

68. Huys J. Cytostatic-associated vomiting effectively inhibited by domperidone (R 33812). Cancer Chenother Pharmacol. 1978;1:215-8.

69. Roila F, Tonato M, Basurto C, Minotti V, Ballatori E, Del Favero A. Double-blind controlled trial of the antiemetic efficacy and toxicity of methylprednisolone (MP), metoclopramide (MTC) and domperidone (DMP) in breast cancer patients treated with i.v. CMF. Eur J Cancer Clin Oncol. 1987;23:615-7.

70. Baker JJ, Lokey JL, Price NA, Winokur SH, Bowen J. Nabilone as an antiemetic (use of high dose dexamethasone). N Engl J Med. 1979;301:728.

71. Markman M, Sheidler V, Ettinger DS, Quaskey SA, Mellits ED. Antiemetic efficacy of dexamethasone. Randomized, doubleblind, crossover study with prochlorperazine in patients receiving cancer chemotherapy. N Engl J Med. 1984;311:549-52.

72. Roila F, Tonato M, Cognetti F, Cortesi F, Favalli G, Marangolo M, Amadori D, Bella MA, Gramazio V, Donati D, Ballatori E, Del Favero A. Prevention of cisplatin-induced emesis: a double-blind multicenter randomized crossover study comparing ondansetron and ondansetron plus dexamethasone. J Clin Oncol. 1991;9:675-8.

73. The Italian Group for Antiemetic Research. Dexamethasone, granisetron or both for the prevention of nausea and vomiting during chemotherapy for cancer. N Engl J Med. 1995;332:1-5.

74. Leibundgut U, Lancranjan I. First results with ICS 205-930 (5-HT3 receptor antagonis) in prevention of chemotherapyinduced emesis. Lancet. 1987;1(8543):1198.

75. Cunningham D, Hawthorn J, Pople A, Gazet J-C, Ford HT, Challoner T, Coombes RC. Prevention of emesis in patients receiving cytotoxic drugs by GR38032F, a selective 5-HT3 receptor antagonist. Lancet. 1987;1(8548):1461-3.

76. Cubeddu LX, Hoffmann IS, Fuenmayor NT, Finn AL. Efficacy of ondansetron (GR 38032F) and the role of serotonin in cisplatininduced nausea and vomiting. N Engl J Med. 1990;322:810-6.

77. Cubeddu LX, Hoffman IS, Fuenmayor NT, Finn AL. Antagonism of serotonin S3 receptors with ondansetron prevents nausea and emesis induced by cyclophosphamide-containing chemotherapy regimens. J Clin Oncol. 1990;8:1721-7.

78. Marty M, Pouillart P, Scholl S, Droz JP, Azab M, Brion N, Pujade-Lauraine E, Paule B, Paes D, Bons J. Comparison of the 5-hydroxytryptamine3 (serotonin) antagonist ondansetron (GR 38032F) with high-dose metoclopramide in the control of cisplatin-induced emesis. N Engl J Med. 1990;322:816-21.

79. Bonneterre J, Chevallier B, Metz R, Fargeot P, Pujade-Lauraine E, Spielmann M, Tubiana-Hulin M, Paes D, Bons J. A randomized double-blind comparison of ondansetron and metoclopramide in the prophylaxis of emesis induced by cyclophosphamide, fluorouracil, and doxorubicin or epirubicin chemotherapy. J Clin Oncol. 1990;8:1063-9.

80. Kaasa S, Kvaløy S, Dicato MA, Ries F, Huys JV, Royer E, Carruthers L, International Emesis Study Group. A comparison of ondansetron with metoclopramide in the prophylaxis of chemotherapy-induced nausea and vomiting: a randomized, doubleblind study. International Emesis Study Group. Eur J Cancer. 1990;26:311-4. 
81. Marschner NW, Adler M, Nagel GA, Christmann D, Fenzl E, Upadhyaya B. Double-blind randomised trial of the antiemetic efficacy and safety of ondansetron and metoclopramide in advanced breast cancer patients treated with epirubicin and cyclophosphamide. Eur J Cancer. 1991;27:1137-40.

82. Jones AL, Hill AS, Soukop M, Hutcheon AW, Cassidy J, Kaye SB, Sikora K, Carney DN, Cunningham D. Comparison of dexamethasone and ondansetron in the prophylaxis of emesis induced by moderately emetogenic chemotherapy. Lancet. 1991;24(338):483-7.

83. Warr D, Willan A, Fine S, Wilson K, Davis A, Erlichman C, Rusthoven J, Lofters W, Osoba D, Laberge F, Latreille J, Pater J. Superiority of granisetron to dexamethasone plus prochlorperazine in the prevention of chemotherapy-induced emesis. J Natl Cancer Inst. 1991;83:1169-73.

84. Warr D, Wilan A, Venner P, Pater J, Kaizer L, Laberge F, Latreille J, Stewart D, O'Connell G, Osoba D, Wilson K, Davis A, Johnston D. A randomised, double-blind comparison of granisetron with high-dose metoclopramide, dexamethasone and diphenhydramine for cisplatin-induced emesis. An NCI Canada Clinical Trials Group Phase III Trial. Eur J Cancer. 1992;29A:33-6.

85. Perez EA, Hesketh P, Sandbach J, Reeves J, Chawla S, Markman M, Hainsworth J, Bushnell W, Friedman C. Comparison of single-dose oral granisetron versus intravenous ondansetron in the prevention of nausea and vomiting induced by moderately emetogenic chemotherapy: a multicenter, double-blind, randomized parallel study. J Clin Oncol. 1998;16:754-60.

86. Gralla RJ, Navari RM, Hesketh PJ, Popovic W, Strupp J, Noy J, Einhorn L, Ettinger D, Bushnell W, Friedman C. Singledose oral granisetron has equivalent antiemetic efficacy to intravenous ondansetron for highly emetogenic cisplatin-based chemotherapy. J Clin Oncol. 1998;16:1568-73.

87. Raftopoulos H, Cooper W, O'Boyle E, Gabrail N, Boccia R, Gralla RJ. Comparison of an extended-release formulation of granisetron (APF530) versus palonosetron for the prevention of chemotherapy-induced nausea and vomiting associated with moderately or highly emetogenic chemotherapy: results of a prospective, randomized, double-blind, noninferiority, phase 3 trial. Support Care Cancer. 2015;23:723-32.

88. Gralla R, Lichinitser M, Van der Vegt S, Sleeboom H, Mezger J, Peschel C, Tonini G, Labianca R, Macciocchi A, Aapro M. Palonosetron improves prevention of chemotherapy-induced nausea and vomiting following moderately emetogenic chemotherapy: results of a double-blind randomized phase III trial comparing single doses of palonosetron with ondansetron. Ann Oncol. 2003;14:1570-7.

89. Eisenberg P, Figueroa-Vadillo J, Zamora R, Charu V, Hajdenberg J, Cartmell A, Macciocchi A, Grunberg S. Improved prevention of moderately emetogenic chemotherapy-induced nausea and vomiting with palonosetron, a pharmacologically novel 5-HT 3 receptor antagonist. Cancer. 2003;98:2473-82.

90. Aapro MS, Grunberg SM, Manikhas GM, Olivares G, Suarez T, Tjulandin SA, Bertoli LF, Yunus F, Morrica B, Lordick F, Macciocchi A. A phase III, double-blind, randomized trial of palonosetron compared with ondansetron in preventing chemotherapy-induced nausea and vomiting following highly emetogenic chemotherapy. Ann Oncol. 2006;17:1441-9.

91. Saito M, Aogi K, Sekine I, Yoshizawa H, Yanagita Y, Sakai H, Inoue K, Kitagawa C, Ogura T. Palonosetron plus dexamethasone versus granisetron plus dexamethasone for prevention of nausea and vomiting during chemotherapy: a double-blind, double-dummy, randomised, comparative phase III trial. Lancet Oncol. 2009; 10:115-24.

92. Morganroth J, Flaharty KK, Parisi S, Moresino C. Effect of single doses of IV palonosetron, up to $2.25 \mathrm{mg}$, on the
QTC interval duration: a double-blind, randomized, parallel group study in healthy volunteers. Support Care Cancer. 2016;24:621-7.

93. Min JJ, Yoo Y, Kim TK, Lee J-M. Intravenous palonosetron increases the incidence of $\mathrm{QT}_{\mathrm{C}}$ prolongation during sevoflurane general anesthesia for laparotomy. Korean J Anesthesiol. 2013;65:397-402.

94. Prasad M, Shashidar VK, Chakraborty A. Palonosetron-induced ventricular tachycardia in a patient receiving cancer chemotherapy. Cureus. 2017;9: e1480. https://doi.org/10.7759/cureus.1480.

95. Kaiser R, Sezer O, Papies A, Bauer S, Schelenz C, Tremblay P-B, Possinger K, Roots I, Brockmöller J. Patient-tailored antiemetic treatment with 5-hydroxytryptamine type 3 receptor antagonists according to cytochrome P-450 2D6 genotypes. J Clin Oncol. 2002;20:2805-11.

96. Kris MG, Radford JE, Pizzo BA, Inabinet R, Hesketh A, Hesketh PJ. Use of an NK1 receptor antagonist to prevent delayed emesis after cisplatin. J Natl Cancer Inst. 1997;89:817-8.

97. Navari RM, Reinhardt RR, Gralla RJ, Kris MG, Hesketh PJ, Khojasteh A, Kindler H, Grote TH, Pendergrass K, Grunberg SM, Carides AD, Gertz B, for The L-754,030 Antiemetic Trials Group. Reduction of cisplatin-induced emesis by a selective neurokinin-1-receptor antagonist. L-754,030 Antiemetic Trials Group. N Engl J Med. 1999;340:190-5.

98. Campos D, Pereira JR, Reinhardt RR, Carracedo C, Poli S, Vogel C, Martinez-Cedillo J, Erazo A, Wittreich J, Eriksson L-O, Carides AD, Gertz BJ. Prevention of cisplatin-induced emesis by the oral neurokinin-1 antagonist, MK-869, in combination with granisetron and dexamethasone or with dexamethasone alone. J Clin Oncol. 2001;19:1759-67.

99. Cocquyt V, Van Belle S, Reinhardt RR, Decramer MLA, O’Brien M, Schellens JHM, Borms M, Verbeke L, Van Aelst F, De Smet M, Carides AD, Eldridge K, Gertz BJ. Comparison of L-758,298, a prodrug for the selective neurokinin-1 antagonist, L-754,030, with ondansetron for the prevention of cisplatin-induced emesis. Eur J Cancer. 2001;37:835-42.

100. Van Belle S, Lichinitser MR, Navari RM, Garin AM, Decramer MLA, Riviere A, Thant M, Brestan E, Bui B, Eldridge K, De Smet M, Michiels N, Reinhardt RR, Carides AD, Evans JK, Gertz BJ. Prevention of cisplatin-induced acute and delayed emesis by the selective neurokinin-1 antagonists, L-758,298 and MK-869. Cancer. 2002;94:3032-41.

101. Chawla SP, Grunberg SM, Gralla RJ, Hesketh PJ, Rittenberg C, Elmer ME, Schmidt C, Taylor A, Carides AD, Evans JK, Horgan KJ. Establishing the dose of the oral NK1 antagonist aprepitant for the prevention of chemotherapy-induced nausea and vomiting. Cancer. 2003;97:2290-300.

102. Hesketh PJ, Grunberg SM, Gralla RJ, Warr DG, Roila F, De Wit R, Chawla SP, Carides AD, Ianus J, Elmer ME, Evans JK, Beck K, Reines S, Horgan KJ. The oral neurokinin-1 antagonist aprepitant for the prevention of chemotherapy-induced nausea and vomiting: a multinational, randomized, doubleblind, placebo-controlled trial in patients receiving high-dose cisplatin-the Aprepitant Protocol 052 Study Group. J Clin Oncol. 2003;21:4112-9.

103. Poli-Bigelli S, Rodrigues-Pereira J, Carides AD, Ma GJ, Eldridge K, Hipple A, Evans JK, Horgan KJ, Lawson F, on behalf of the Aprepitant Protocol 054 Study Group. Addition of the neurokinin 1 receptor antagonist aprepitant to standard antiemetic therapy improves control of chemotherapy-induced nausea and vomiting. Results from a randomized, double-blind, placebo-controlled trial in Latin America. Cancer. 2003;97:3090-8.

104. Schmoll HJ, Aapro MS, Poli-Bigelli S, Kim H-H, Park K, Jordan K, Von Pawel J, Giezek H, Ahmed T, Chan CY. Comparison of an aprepitant regimen with a multiple-day ondansetron regimen, 
both with dexamethasone, for antiemetic efficacy in high-dose cisplatin treatment. Ann Oncol. 2006;17:1000-6.

105. Warr DG, Hesketh PJ, Gralla RJ, Muss HB, Herrstedt J, Eisenberg PD, Raftopoulos H, Grunberg SM, Gabriel M, Rodgers A, Bohidar N, Klinger G, Hustad CM, Horgan KJ, Skobieranda F. Efficacy and toilerability of aprepitant for the prevention of chemotherapy-induced nausea and vomiting in patients with breast cancer after moderately emetogenic chemotherapy. J Clin Oncol. 2005;23:2822-30.

106. Rapoport BL, Jordan K, Boice JA, Taylor A, Brown C, Hardwick JS, Carides A, Webb T, Schmoll H-J. Aprepitant for the prevention of chemotherapy-induced nausea and vomiting associated with a broad range of moderately emetogenic chemotherapies and tumor types: a randomized, double-blind study. Support Care Cancer. 2010;18:423-31.

107. Herrstedt J, Muss HB, Warr DG, et al. Efficacy and tolerability of aprepitant for the prevention of chemotherapy-induced nausea and emesis over multiple cycles of moderately emetogenic chemotherapy. Cancer. 2005;104:1548-55.

108. Grunberg S, Chua D, Maru A, Dinis J, DeVandry S, Boice JA, Hardwick JS, Beckford E, Taylor A, Carides A, Roila F, Herrstedt J. Single-dose fosaprepitant for the prevention of chemotherapy-induced nausea and vomiting associated with cisplatin therapy: randomized, double-blind study protocol-EASE. J Clin Oncol. 2011;29:1495-501.

109. Hesketh PJ, Rossi G, Rizzi G, et al. Efficacy and safety of NEPA, an oral combination of netupitant and palonosetron, for prevention of chemotherapy-induced nausea and vomiting following highly emetogenic chemotherapy: a randomized dose-ranging pivotal study. Ann Oncol. 2014;25:1340-6.

110. Aapro M, Rugo H, Rossi G, et al. A randomized phase III study evaluating the efficacy and safety of NEPA, a fixed-dose combination of netupitant and palonosetron, for prevention of chemotherapy-induced nausea and vomiting following moderately emetogenic chemotherapy. Ann Oncol. 2014;25:1328-33.

111. Aapro M, Karthaus M, Schwartzberg L, Bondarenko I, Sarosiek T, Oprean C, Cardona-Huerta S, Hansen V, Rossi G, Rizzi G, Borroni ME, Rugo H. NEPA, a fixed oral combination of netupitant and palonosetron, improves control of chemotherapyinduced nausea and vomiting (CINV) over multiple cycles of chemotherapy: results of a randomized, double-blind, phase 3 trial versus oral palonosetron. Support Care Cancer. 2017;25:1127-35.

112. Gralla RJ, Bosnjak SM, Hontsa A, et al. A phase III study evaluating the safety and efficacy of NEPA, a fixed-dose combination of netupitant and palonosetron, for prevention of chemotherapyinduced nausea and vomiting over repeated cycles of chemotherapy. Ann Oncol. 2014;25:1333-9.

113. Schwartzberg L, Roeland E, Andric Z, Kowalski D, Radic J, Voisin D, Rizzi G, Navari R, Gralla RJ, Karthaus M. Phase III safety study of intravenous NEPA: a novel fixed antiemetic combination of fosnetupitant and palonosetron in patients receiving highly emetogenic chemotherapy. Ann Oncol. 2018;29:1535-40.

114. Schwartzberg L, Navari R, Clark-Snow R, Arkania E, Radyukova I, Patel K, Voisin D, Rizzi G, Wickham R, Gralla RJ, Aapro M, Roland E. Phase IIIB safety and efficacy of intravenous NEPA for prevention of chemotherapy-induced nausea and vomiting $(\mathrm{CINV})$ in patients with breast cancer receiving initial and repeat cycles of anthracycline and cyclophosphamide (AC) chemotherapy. Oncologist. 2020;25:e589-97.

115. Rapoport B, Chua D, Poma A, Arora S, Wang Y, Fein LE. Study of rolapitant, a novel, long-acting, NK-1 receptor antagonist, for the prevention of chemotherapy-induced nausea and vomiting (CINV) due to highly emetogenic chemotherapy (HEC). Support Care Cancer. 2015;23:3281-8.
116. Rapoport BL, Chasen MR, Gridelli C, Urban L, Modiano MR, Schnadig ID, Poma A, Arora S, Kansra V, Schwartzberg LS, Navari RM. Safety and efficacy of rolapitant for prevention of chemotherapy-induced nausea and vomiting after administration of cisplatin-based highly emetogenic chemotherapy in patients with cancer: two randomised, active-controlled, double-blind, phase 3 trials. Lancet Oncol. 2015;16:1079-89.

117. Schwartzberg LS, Modiano MR, Rapoport BL, Chasen MR, Gridelli C, Urban L, Poma A, Arora S, Navari RM, Schnadig ID. Safety and efficacy of rolapitant for prevention of chemotherapy-induced nausea and vomiting after administration of moderately emetogenic chemotherapy or anthracycline and cyclophosphamide regimens in patients with cancer: a randomised, active-controlled, double-blind, phase 3 trial. Lancet Oncol. 2015;16:1071-8.

118. Navari RM. The safety of rolapitant for the treatment of nausea and vomiting associated with chemotherapy. Exp Opin Drug Saf. 2019;18:1127-32.

119. Walton GD. Safety profile of HTX-019 administered as an intravenous push in cancer patients: a retrospective review. Adv Ther. 2019;36:662-9.

120. Meiri E, Jhangiani H, Vredenburgh JJ, Barbato LM, Carter FJ, Yang H-M, Baranowski V. Efficacy of dronabinol alone and in combination with ondansetron versus ondansetron alone for delayed chemotherapy-induced nausea and vomiting. Curr Med Res Opin. 2007;23:533-43.

121. Grimison R, Mersiades A, Kirby A, Lintzeris N, Morton R, Haber R, Olver I, Walsh A, McGregor I, Cheung Y, Tognela A, Hahn C, Briscoe K, Aghmesheh M, Fox P, Abdi E, Clarke S, Della-Fiorentina S, Shannon J, Gedye C, Begbie S, Simes J, Stockler M. Oral TCH: CBD cannabis extract for refractory chemotherapy-induced nausea and vomiting: a randomized, placebo-controlled, phase 2 crossover trial. Ann Oncol. 2020;31:1553-60.

122. Chow R, Valdez C, Chow N, Zhang D, Im J, Sodhi E, Lock M. Oral cannabinoid for the prophylaxis of chemotherapy-induced nausea and vomiting - a systematic review and meta-analysis. Support Care Cancer. 2020;28:2095-103.

123. Bymaster FP, Rasmussen K, Calligaro DO, Nelson DL, DeLapp NW, Wong DT, Moore NA. In vitro and in vivo biochemistry of olanzapine: a novel, atypical antipsychotic drug. J Clin Psychiatry. 1997;58(suppl 10):28-36.

124. Navari RM, Einhorn LH, Passik SD, Loehrer PJ Sr, Johnson C, Mayer ML, McClean J, Vinson J, Pletcher W. A phase II trial of olanzapine for the prevention of chemotherapy-induced nausea and vomiting: a Hoosier Oncology Group Study. Support Care Cancer. 2005; 13:529-34.

125. Navari RM, Einhorn LH, Loehrer PJ Sr, Passik SD, Vinson J, McClean J, Chowhan N, Hanna NH, Johnson CS. A phase II trial of olanzapine, dexamethasone, and palonosetron for the prevention of chemotheraåy-induced nausea and vomiting: a Hoosier Oncology Group Study. Support Care Cancer. 2007;15:1285-91.

126. Yanai $\mathrm{T}$, Iwasa $\mathrm{S}$, Hashimoto $\mathrm{H}$, Ohyanagi $\mathrm{F}$, Takiguchi $\mathrm{T}$, Takeda K, Nakao M, Sakai H, Nakayama T, Minato K, Arai T, Suzuki K, Shimada Y, Nagashima K, Terakado H, Yamamoto N. A randomized, double-blind phase II dose-finding study of olanzapine $10 \mathrm{mg}$ or $5 \mathrm{mg}$ for the prophylaxis of emesis induced by highly emetogenic cisplatin-based chemotherapy. Int J Clin Oncol. 2018;23:382-8.

127. Tanaka K, Inui N, Karayama M, Yasui H, Hozumi H, Suzuki Y, Furuhashi K, Fujisawa T, Enomoto N, Nakamura Y, Kusagaya H, Matsuura S, Uto T, Hashimoto D, Matsui T, Asada K, Suda T. Olanzapine-containing antiemetic therapy for the prevention of carboplatin-induced nausea and vomiting. Cancer Chemother Pharmacol. 2019;84:147-53. 
128. Navari RM, Gray SE, Kerr AC. Olanzapine versus aprepitant for the prevention of chemotherapy-induced nausea and vomiting: a randomized phase III trial. J Support Oncol. 2011;9:188-95.

129. Navari RM, Qin R, Ruddy KJ, Liu H, Powell SF, Bajaj M, Dietrich L, Biggs D, Lafky JM, Loprinzi CL. Olanzapine for the prevention of chemotherapy-induced nausea and vomiting. N Engl J Med. 2016;375:134-42.

130. Hashimoto H, Abe M, Tokuyama O, Mizutani H, Uchitomi Y, Yamaguchi T, Hoshina Y, Sakata Y, Takashi TY, Nakashima K, Nakao M, Takei D, Zenda S, Mizukami K, Iwasa S, Sakurai M, Yamamoto N, Ohe Y. Olanzapine $5 \mathrm{mg}$ plus standard antiemetic therapy for the prevention of chemotherapy-induced nausea and vomiting (J-FORCE): a multicenter, randomized, double-blind, placebo-controlled trial. Lancet Oncol. 2020;21:242-9.

131. Chow R, Herrstedt J, Aapro M, Chiu L, Lam H, Prsic E, Lock M, DeAngelis C, Navari RM. Olanzapine for the prophylaxis and rescue of chemotherapy-induced nausea and vomiting: a systematic review, meta-analysis, cumulative meta-analysis and fragility assessment of the literature. Support Care Cancer. 2021;29:3439-59.

132. Zhou J-G, Huang L, Jin S-H, Xu C, Frey B, Ma H, Gaipl US. Olanzapine combined with 5-hydroxytryptamine type 3 receptor antagonisy (5-HT3RA) plus dexamethasone for prevention and treatment of chemotherapy-induced nausea and vomiting in high and moderate emetogemic chemotherapy: a systematic review and meta-analysis of randomized controlled trials. ESMP Open. 2020;5: e000621. https://doi.org/10.1136/esmoo pen-2019-000621.

133. Roila F, Molassiotis A, Herrstedt J, Aapro M, Gralla RJ, Bruera E, Clark-Snow RA, Dupuis LL, Einhorn LH, Feyer P, Hesketh PJ, Jordan K, Olver I, Rapoport BL, Roscoe J, Ruhlmann CH, Walsh $\mathrm{D}$, Warr D, Van der Wetering M, on behalf of the participants of MASCC/ESMO Consensus Conference Copenhagen 2015. 2016 MASCC and ESMO guideline update for the prevention of chemotherapy- and radiotherapy-induced nausea and vomiting and of nausea and vomiting in advanced cancer patients. Ann Oncol. 2016;27:v119-33.

134. MASCC/ESMO Antiemetic Guideline 2016 with updates in 2019. https://mascc.memberclicks.net/mascc-guidelines. Accessed 23 Aug 2021.

135. Hesketh PJ, Kris MG, Basch E, Bohlke K, Barbour SY, ClarkSnow RA, Danso MA, Dennis K, Dupuis L, Dusetzina SB, Eng C, Feyer PC, Jordan K, Noonan K, Sparacio D, Lyman GH. Antiemetics: ASCO guideline update. J Clin Oncol. 2020;38:2782-97.

136. Antiemesis: Version 1.2021. Ettiner DS, Berger MJ, Anand S, Babour S, Bergsbaken J, Brandt D, Brown GE, Crews JR, Hong C, Kim EJ, Kirkegaard S, Kloth DD, Klute K, Kris MG, Lim D, Ma CX, Maurer V, McAlister RK, Mehta R, Noonan K, Riebrandt G, Roeland E, Rogers JE, Rugo HS, Saunders I, Scullion B, Silveira M, Wolf A. https://www.nccn.org/professionals/physi cian_gls/pdf/antiemesis.pdf. Accessed 30 Aug 2021.

137. Martin M, Diaz-Rubio E, Sanchez A, Almenarez J, López-Vega JM. The natural course of emesis after carboplatin treatment. Acta Oncol. 1990;29:593-5.

138. Ludmir EB, Mainwaring W, Lin TA, Miller AB, Jethanandani A, Espinoza AF, Mandel JJ, Lin SH, Smith BD, Smith GL,
VanderWalde NA, Minsky BD, Koong AC, Stinchcombe TE, Jagsi R, Gomez DR, Thomas CR, Fuller CD. Factors associated with age disparities among cancer clinical trial participants. JAMA Oncol. 2019;5:1769-73.

139. Lackman M, Vickers MM, Hsu T. Physician-reported reasons for non-enrollment of older adults in cancer clinical trials. J Geriatr Oncol. 2020;11:31-6.

140. Malakoff D. Spiraling costs threaten gridlock. Science. 2008;322:210-3.

141. Celio L, Bonizzoni E, Bajetta E, Sebastiani S, Perrone T, Aapro MS. Palonosetron plus single-dose dexamethasone for the prevention of nausea and vomiting in women receiving anthracycline/cyclophosphamide-containing chemotherapy: meta-analysis of individual patient data examining the effect of age on outcome in two phase III trials. Support Care Cancer. 2013;21:565-73.

142. Ito Y, Tsuda T, Minatogawa H, Kano S, Sakamaki K, Ando M, Tsugawa K, Kojima Y, Furuya N, Matsuzaki K, Fukuda M, Sugae S, Ohta I, Arioka H, Tokuda Y, Narui K, Tsuboya A, Suda T, Morita S, Boku N, Yamanaka T, Nakajima TE. Placebo-controlled, double-blind phase III study comparing dexamethasone on day 1 with dexamethasone on days 1 to 3 with combined neurokinin-1 receptor antagonist and palonosetron in high-emetogenic chemotherapy. J Clin Oncol. 2018;36:1000-6.

143. Celio L, Cortinovis D, Cogoni AA, Cavanna L, Martelli O, Carnio S, Collova E, Bertolini F, Petrelli F, Cassano A, Chiari R, Zanelli F, Pisconti S, Vittimberga I, Letizia A, Misino A, Gernone A, Bonizzoni E, Pilotto S, De Placido S, Bria E. Dexamethasone-sparing regimens with oral netupitant and palonosetron for the prevention of emesis caused by high-dose cisplatin: a randomized non-inferiority study. Oncologist. 2021. https://doi. org/10.1002/onco.13851.

144. Hayashi T, Shimokawa M, Mizuki F, Matsuo K, Kawada K, Nakano T, Egawa T. Efficacy of one-day versus multiple-day dexamethasone for chemotherapy-induced nausea and vomiting in lung cancer patients receiving carboplatin-based chemotherapy: a propensity score-matched analysis. Support Care Cancer. 2021;29:5029-35.

145. Janowitz T, Kleeman S, Vonderheide RH. Reconsidering dexamethasone for antiemesis when combining chemotherapy and immunotherapy. Oncologist. 2021;26:269-73.

146. Grant RC, Rotstein C, Liu G, Forbes L, Vu K, Lee R, Ng P, Krzyzanowska M, Warr D, Knox J. Reducing dexamethasone antiemetic prophylaxis during the COVID-19 pandemic: recommendations from Ontario, Canada. Support Care Cancer. 2020;28:5031-6.

147. Chapell R, Aapro MS. Efficacy of aprepitant among patients aged 65 and over receiving moderately to highly emetogenic chemotherapy: a meta-analysis of unpublished data from previously published studies. J Geriatr Oncol. 2013;4:73-83.

148. Aapro M, Jordan K, Gralla RJ, Rizzi G, Rossi G, Palmas M, Alyasova AV, Lisyanskaya AS, Bosnjak S, Hesketh PJ. Safety and efficacy of NEPA, an oral fixed combination of netupitant and palonosetron in older patients. J Geriatr Oncol. 2017;8:56-63. 